\title{
MODELLING THE EFFECTS OF BIOGENIC NOx EMISSIONS ON THE SOUTH AFRICAN HIGHVELD AND WATERBERG REGIONS
}

\author{
Adamus Paulus Bruwer and Gerrit Kornelius \\ Environmental Engineering Group, Department of Chemical Engineering, University of \\ Pretoria., South Africa, \\ Corresponding author: gerrit.kornelius@up.ac.za
}

\begin{abstract}
The Highveld and Waterberg regions in South Africa contain extensive coal fields and therefore have a high concentration of coal fired power stations. Previous studies assessed the impact of atmospheric deposition of $\mathrm{S}$ - and $\mathrm{N}$-containing species from anthropogenic sources in the region, but did not include the effect of biogenic emissions. This study models biogenic NOx soil emissions for the regions and includes them in an atmospheric dispersion model to study the effects biogenic emission on nitrogen deposition rates. Simulated sulfur deposition rates for the Highveld area are also reported on.
\end{abstract}

Anthropogenic and biogenic sulfur and nitrogen emission sources were inventoried for the Highveld and Waterberg regions. Using previous work by Yienger and Levy, biogenic soil NOx emissions were quantified by constructing models for both areas using land use data, rainfall data and atmospheric ground level temperatures from CALMET data. A CALPUFF dispersion model was used to predict deposition rates for $\mathrm{S}$ - and $\mathrm{N}$-containing species with and without biogenic $\mathrm{NO}_{x}$ emissions to determine the impact of biogenic emissions for the Highveld. As rainfall is highly variable in the region, meteorological data representative of high, average and low rainfall years was used to determine the effect of rainfall on deposition rates for the various species.

The biogenic $\mathrm{NO}_{x}$ made up $3.96 \%, 4.14 \%$ and $3.34 \%$ of total released $\mathrm{NO}_{x}$ for 2001 (average rainfall), 2003 (low rainfall) and 2010 (high rainfall) respectively. Dry nitrogen deposition rates were affected most by the biogenic component, adding from $1.7-6.2 \%$ at various receptor locations. Wet deposition rates were affected very little $(0.13 \%$ to 
$0.75 \%)$. Effect on total nitrogen deposition rates ranged from $0.32 \%$ to $1.77 \%$. Biogenic emissions for the Waterberg area, being more arid, were calculated to be only $2.3 \%$ of total $\mathrm{NO}_{\mathrm{x}}$ emissions for the area and accordingly have little effect on deposition rates.

Keywords: South African Highveld, South African Waterberg, biogenic NOx emissions, deposition modelling. 


\section{INTRODUCTION}

The deposition of nitrogen and sulfur species on the South African Highveld has been studied for at least four decades, because most of the country's coal power generation facilities and coal-based petrochemical industries were developed since the mid-1950s on the coal fields in this area. Total installed coal-based power generation capacity is approximately $32700 \mathrm{MW}$, with an additional $4800 \mathrm{MW}$ being commissioned from 2016 onwards (Pretorius 2015). Anthropogenic sulfur oxide emissions in the region were estimated at approximately 1.6 million ton per annum and nitrogen oxide emissions at close to 1 million ton per annum in 2008 (Scorgie and Kornelius 2009, Pretorius 2015).

These emissions have led to high values for the deposition of $S$ and $N$ species. Bluff et al. (1991) collected data from an acid rain network from 1985 to 1990 to calculate annual average wet sulfur deposition on the Highveld. Values ranged from $5.8 \mathrm{~kg} \mathrm{~S} \mathrm{ha-}$ ${ }^{1} \mathrm{yr}^{-1}$ (central Highveld) to $4.7 \mathrm{~kg} \mathrm{~S} \mathrm{ha}^{-1} \mathrm{yr}^{-1}$ on the south-eastern periphery. Zunckel (1995) found total sulfur deposition flux at Elandsfontein (situated centrally in the Highveld area) to $13.1 \mathrm{~kg} \mathrm{ha}^{-1} \mathrm{yr}^{-1}$ with $83 \%$ due to $\mathrm{SO}_{2}$ and the rest to sulfate while Mphepya and Held (1999) reported $7.5 \mathrm{~kg} \mathrm{ha}^{-1} \mathrm{yr}^{-1}$ total S deposition at Amersfoort, situated south-easterly. Galy-Lacaux et al. (2003) reported total nitrogen deposition rates at Amersfoort of $15 \mathrm{~kg} \mathrm{~N} \mathrm{ha}^{-1} \mathrm{yr}^{-1} .63 \%\left(9.45 \mathrm{~kg} \mathrm{~N} \mathrm{ha}^{-1} \mathrm{yr}^{-1}\right)$ of this was due to wet deposition, while 37\% was due to dry deposition. In 2003 Lowman (2003) estimated that total wet deposition for the Highveld ranged from 6.5 to $10.6 \mathrm{~kg} \mathrm{~N} \mathrm{ha}^{-1} \mathrm{yr}^{-1}$, with an average of $7.84 \mathrm{~kg} \mathrm{~N} \mathrm{ha}^{-1} \mathrm{yr}^{-1}$.

Josipovic et al. (2011) calculated total acidic deposition rates as part of a study assessing of critical load exceedances over the Highveld area. Deposition rates for two periods_were reported: September 2005 to August 2006 and September 2006 to August 2007. They reported total acidic deposition, which includes both total $\mathrm{S}$ and $\mathrm{N}$ deposition rate values, of $23.5 \mathrm{~kg} \mathrm{ha}^{-1} \mathrm{yr}^{-1}$ and $15.8 \mathrm{~kg} \mathrm{ha}^{-1} \mathrm{yr}^{-1}$ at Elandsfontein, $15.2 \mathrm{~kg}$ $\mathrm{ha}^{-1} \mathrm{yr}^{-1}$ and $11.3 \mathrm{~kg} \mathrm{ha}^{-1} \mathrm{yr}^{-1}$ at Standerton and $19 \mathrm{~kg} \mathrm{ha}^{-1} \mathrm{yr}^{-1}$ and $11.4 \mathrm{~kg} \mathrm{ha}^{-1} \mathrm{yr}^{-1}$ at Amersfoort. These values have led to concerns about the impact thereof on surface and ground water quality. Both source apportionment studies by dispersion modelling 
(Scorgie et al.(2002), Scorgie and Kornelius (2009), Pretorius 2015) and soil impact studies (Bird 2011, Hutchinson 2012) were initiated. Scorgie et al. (2002) and Scorgie and Kornelius (2009) composed an extensive anthropogenic emission inventory for the Highveld and used the US Environmental Protection Agency's CALPUFF Lagrangian puff modelling system to model nitrogen and sulfur deposition. They predicted the spatial and temporal variations in total, wet and dry sulfur and nitrogen deposition rates over the Highveld for three meteorological data sets representing above average, average and below average annual rainfall. This study did however not include biogenic emissions of $\mathrm{N}$ species due to the limited data available at the time.

The present study builds on the work done by Scorgie and Kornelius for the Highveld. Biogenic $\mathrm{NO}_{x}$ sources are estimated for the South African Highveld, a typical grassland area, and the contribution of these sources to the deposition of $\mathrm{N}$ species is modelled.

A more recent area of interest due to the development of a large coal field and two large coal burning power stations of $3990 \mathrm{MW}$ installed and a further $4764 \mathrm{MW}$ being commissioned (Pretorius 2015) since the mid-1970s is the Waterberg area, situated in a savannah area with a different biogenic emissions profile. The anthropogenic emissions for this region have previously been quantified and the concentration and deposition impact thereof modelled (Liebenberg-Enslin et al 2010). In the present study the biogenic emissions for this area were also calculated in order to compare the impact thereof with that of the anthropogenic emissions.

In Figure 1 each priority area is shown on relation to the coal fields and the specific biomes occurring within those areas. Major coal-fired power stations are also shown. 

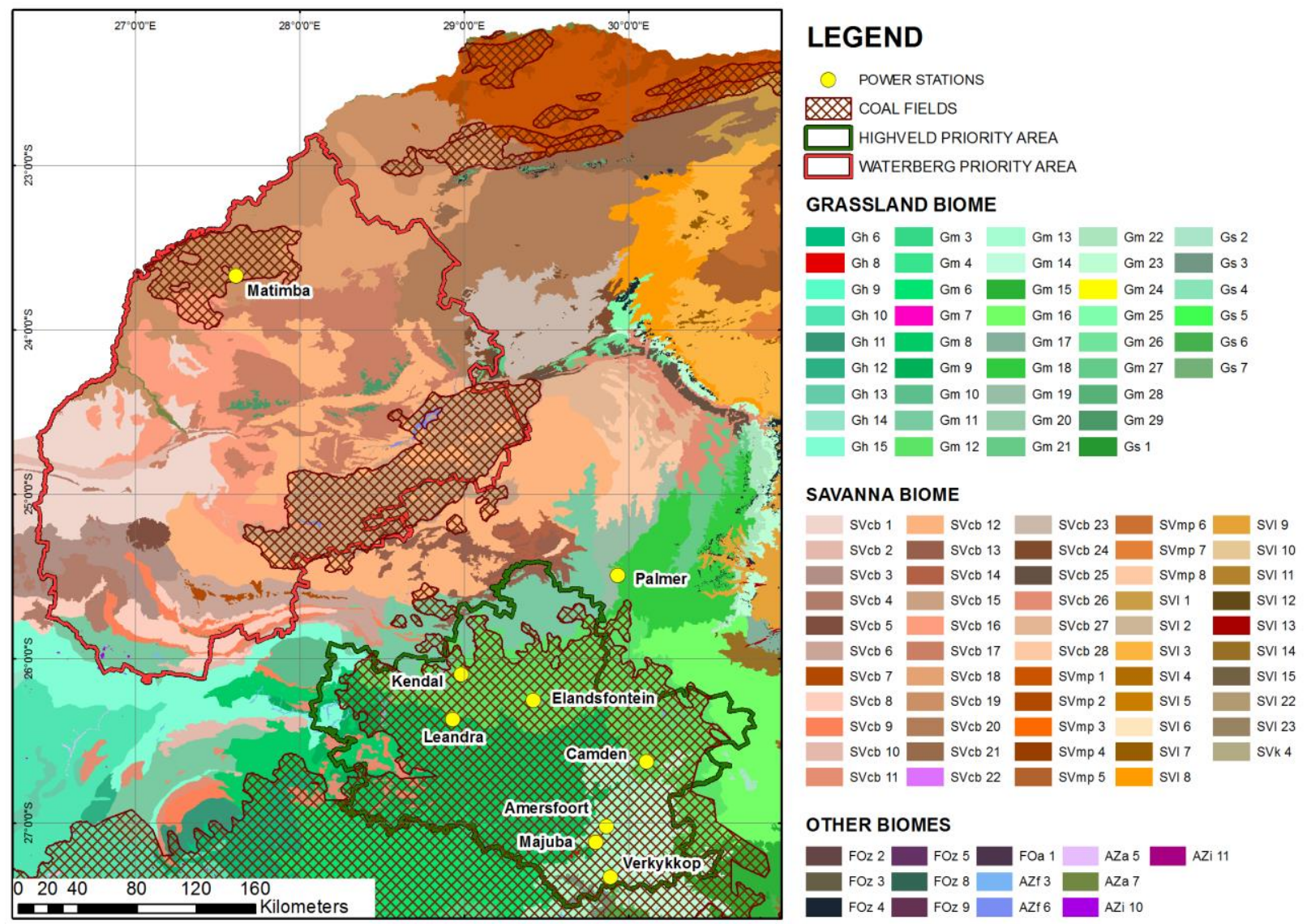

Fig 1: The South African Highveld and Waterberg priority areas in relation to the coal field and specific biomes occurring within the borders of those areas (Rutherford and Powrie, 2009; Merrill and Tewalt, 2008).

The main research objectives were:

- Constructing a comprehensive emission inventory and dispersion model for both the South African Highveld and Waterberg areas.

- Building a comprehensive biogenic $\mathrm{NO}_{x}$ emission model for both areas to study the effect of biogenic $\mathrm{NO}_{x}$ emissions on the deposition of $\mathrm{N}$ species in these regions. 


\section{CALCULATION METHODS}

\subsection{Biogenic emissions}

Biogenic soil emissions have been recognized as important sources of $\mathrm{NO}$ and $\mathrm{N}_{2} \mathrm{O}$ since the early 1990's. Total biogenic NOx emissions from southern Africa are estimated to be about $1 \mathrm{Tg} \mathrm{yr}^{-1}$. Due to long dry seasons and low moisture content of the soil, NO is produced rather than $\mathrm{N}_{2} \mathrm{O}$ and due to the short atmospheric residence time of $\mathrm{NO}$ it is expected that biogenic emissions will play a more important role on a regional scale (Feig 2009; Scholes and Scholes 1998). Two major ecosystems that are present within South Africa are the grasslands of the Highveld, situated east and south of Pretoria and semiarid savanna north and west of Pretoria. The latter includes the Waterberg region.

Most of the work on biogenic $\mathrm{NO}_{x}$ emission within Southern Africa has so far been focused on arid environments such as the Kalahari, and on savannah areas due to their importance to global $\mathrm{NO}_{x}$ emissions (Feig et al. 2008; Scholes et al. 1997). At Nylsvley, Scholes et al. (1997) reported that dry soil produced a NO flux of $2 \mathrm{ng} \mathrm{N}-\mathrm{NO} \mathrm{m^{-2 }} \mathrm{s}^{-1}$, which

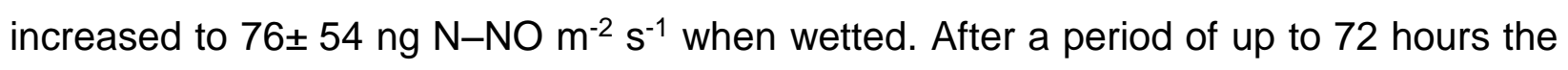
emission rate dropped to between 10 and $30 \mathrm{ng} \mathrm{N}-\mathrm{NO} \mathrm{m}^{-2} \mathrm{~s}^{-1}$. Feig et al. (2008) reported NO fluxes in the Kruger National Park between 0.2 and $0.8 \mathrm{~kg} \mathrm{~N} \mathrm{ha}^{-1} \mathrm{yr}^{-1}$.

Although there has been no attempt at determining biogenic $\mathrm{NO}$ and $\mathrm{N}_{2} \mathrm{O}$ flux rates on the Highveld grassland, internationally grasslands have been studied extensively. In their attempt to estimate global NO emissions Davidson and Kingerlee (1997) included 11 studies done on temperate grassland. They concluded that globally temperate grasslands account for $1.1 \mathrm{Tg} \mathrm{N} \mathrm{yr}^{-1}$ with a mean flux of $1.2 \mathrm{~kg} \mathrm{~N} \mathrm{ha}^{-1} \mathrm{yr}^{-1}$ ranging from $0-1.8 \mathrm{~kg} \mathrm{~N}$ $\mathrm{ha}^{-1} \mathrm{yr}^{-1}$. Hutchinson (2012) conducted a study at the Sandspruit catchment in the southern Mpumalanga (within the Highveld study region) to quantify the effects that acid deposition has on the Highveld soil nutrient cycling processes. A sulfur and nitrogen budget for the soil of the area was constructed. It was assumed that nitrogen loss through denitrification was $5 \%$ of the measured mineralization rates for each scenario and that 
these are represented as a combined $\mathrm{NO}$ and $\mathrm{N}_{2} \mathrm{O}$ flux value. An average emission rates of $2.2 \mathrm{~kg} \mathrm{~N} \mathrm{ha}^{-1} \mathrm{yr}^{-1}$ was calculated.

In the present study, $\mathrm{NO}_{x}$ soil emission calculations for the Highveld and the Waterberg are based on work done by Yienger and Levy (1997), which was used to estimate global NOx emissions. In their study Yienger and Levy determined $\mathrm{NO}_{x}$ flux as a function of soil temperature ( $\left.T_{\text {soil }}\right)$, an emission coefficient that depends on the type of biome (Aw/D), a scalar precipitation pulse value $(\mathrm{P})$ and a scalar factor that accounts for the canopy reduction $(\mathrm{CR})$ effect within biomes that tends to reduce the $\mathrm{NO}_{x}$ flux to the atmosphere (see equation 1 below).

$$
\text { Flux }=f_{W / D}\left(T_{\text {Soil }}, A_{W / D}(\text { Biome })\right) \times P \times C R(L A I, S A I)
$$

Because of the size of the modelling domain and lack of LAI and SAI values for the canopy reduction effect, the canopy reduction factor was assumed to 1 . These values vary by season and land use type and would have added to the complexity of the model, due to the uncertainty in accurately describing the interaction of NOx the canopy (Yienger and Levy 1997).

Several factors such as cloud cover, solar insolation, vegetative cover and soil properties affect the relationship between soil and air temperature. Yienger and Levy made use of empirical relationships that were derived by Williams et al. (1992), which are shown below in Table 1. 
Table 1: Soil and air temperature relationships for different biomes (Williams et al. 1992)

\begin{tabular}{|c|c|}
\hline $\begin{array}{c}\text { Land Use } \\
\text { Type }\end{array}$ & $\begin{array}{c}\text { Estimated Soil } \\
\text { Temperature }\end{array}$ \\
\hline \multicolumn{2}{|c|}{ Natural } \\
\hline Grasslands & $T_{\text {Soil }}=0.66 T_{\text {Air }}+8.8(2)$ \\
\hline Forests & $T_{\text {Soil }}=0.84 T_{\text {Air }}+3.6(3)$ \\
\hline Wetlands & $T_{\text {Soil }}=0.92 T_{\text {Air }}+4.4(4)$ \\
\hline \multicolumn{2}{|c|}{ Agricultural } \\
\hline Corn & $T_{\text {Soil }}=0.72 T_{\text {Air }}+5.8(5)$ \\
\hline Wheat & $T_{\text {Soil }}=1.03 T_{\text {Air }}+2.9(6)$ \\
\hline Soybeans & $T_{\text {Soil }}=1.03 T_{\text {Air }}+2.9(7)$ \\
\hline
\end{tabular}

Soil NO emissions vary with soil moisture content and temperature. Instead of including a term explicitly for soil moisture in a temperature and NO flux relationship, Yienger and Levy fitted an exponential curve to wet soils and linear curve to dry soils using emission data from available literature for different biomes. Soil is classified as dry when the rain rate drops below $0.1 \mathrm{~cm} /$ day and wet if the precipitation is above this (Yienger and Levy 1997).

For wet soils three temperature intervals were chosen to model $\mathrm{NO}_{x}$ emissions as a function of temperature viz. 0 to $10^{\circ} \mathrm{C}, 10$ to $30^{\circ} \mathrm{C}$ and above $30^{\circ} \mathrm{C}$. Between 0 to $10^{\circ} \mathrm{C}$ the rise in $\mathrm{NO}_{x}$ flux with temperature is close to linear, while from 10 to $30^{\circ} \mathrm{C} \mathrm{NO}$ flux increases exponentially. Above $30^{\circ} \mathrm{C}$ the emissions remain constant. Below $0^{\circ} \mathrm{C}$ it was assumed that no emissions take place. In Table 2 below these relationships are shown for each temperature interval (Yienger and Levy 1997).

Table 2: Wet soil NOx flux temperature dependencies (Yienger and Levy 1995)

\begin{tabular}{|c|lc|}
\hline 0 to $10^{\circ} \mathrm{C}$ & $f_{w}=0.28 \times A_{w}($ biome $) \times T$ & $(8)$ \\
\hline 10 to $30^{\circ} \mathrm{C}$ & $f_{w}=A_{w}($ biome $) \times e^{(0.103 \pm 0.04) \times T}$ & $(9)$ \\
\hline$>30^{\circ} \mathrm{C}$ & $f_{w}=21.97 \times A_{w}($ biome $)$ & $(10)$ \\
\hline
\end{tabular}


The exponential $\mathrm{k}$ value $(0.103 \pm 0.04)$ for the 10 to $30^{\circ} \mathrm{C}$ interval (see eq 9 , table 2.2) was assumed by Yienger and Levy to be globally constant and was calculated from a range of exponential temperature dependencies for wide range of biomes for which $\mathrm{k}$ values was available. Aw for each biome was calculated by applying available $\mathrm{NO}_{x}$ flux data and temperature measurements to equations 8 to 10 (Yienger and Levy 1997).

Dry soils do not have the same well-defined dependencies on temperature that wet soils have. In this case, only two temperature intervals were used to calculate $\mathrm{NO}_{x}$ flux rate: between 0 and $30^{\circ} \mathrm{C}$ the flux rate increases linearly and above $30^{\circ} \mathrm{C}$ a constant flux rate is reached. These relationships are shown in Table 3 (Yienger and Levy 1997).

Table 3: Dry soil temperature relationships (Yienger and Levy 1995)

\begin{tabular}{|c|ll|}
\hline 0 to $30^{\circ} \mathrm{C}$ & $f_{d}=\left(A_{d}(\right.$ biome $\left.) \times T\right) / 30$ & $(11)$ \\
\hline$>30^{\circ} \mathrm{C}$ & $f_{d}=A_{d}($ biome $)$ & $(12)$ \\
\hline
\end{tabular}

To distinguish between heavy, long lasting pulses and short term pulses a scheme was developed and is shown below in Table 4 . As stated above, for rainfall below $0.1 \mathrm{~cm} /$ day the soil is dry and no pulse is emitted. For higher rainfall, pulses vary in size and increase with the precipitation. A pulse decays exponentially with time after the initial release. The duration of each pulse depends on the amount of rainfall in the area and varies from 3 days to 2 weeks (Yienger and Levy 1997).

Table 4: Pulse scheme (Yienger and Levy 1995)

\begin{tabular}{|l|l|l|}
\hline $\begin{array}{l}\text { Rain rate } \\
\text { (cm/day) }\end{array}$ & $\begin{array}{l}\text { Pulse description (F } \\
\text { flux rate) }\end{array}$ & $\begin{array}{l}\text { Event } \\
\text { description }\end{array}$ \\
\hline Rain $<0.1$ & No pulse & No Rain \\
\hline $0.1<$ Rain $<0.5$ & $\begin{array}{l}\text { 3-day pulse, starting at } 5 \times F_{N} \text { with exponential } \\
\text { decay }\end{array}$ & Sprinkle \\
\hline $0.5<$ Rain $<1.5$ & $\begin{array}{l}1 \text { week pulse, starting at } 10 \times F_{N} \text { with } \\
\text { exponential decay }\end{array}$ & Shower \\
\hline $1.5<$ Rain & $\begin{array}{l}\text { 2-week pulse, starting at } 15 \times F_{N} \text { with } \\
\text { exponential decay }\end{array}$ & Heavy Rain \\
\hline
\end{tabular}


The temporal patterns for each type of pulse are shown below in Table 5. A pulse will decrease continuously and will not stop if a new pulse starts or if one is already occurring within a specific area.

Table 5: NOx pulse temporal patterns, $t$ = days (Yienger and Levy 1995)

\begin{tabular}{|l|l|}
\hline No Pulse & $P=1.0$ \\
\hline Sprinkle & $P=11.19 \times e^{-0.805\left[\text { day }^{-1}\right] \times t}(1<t<3)$ \\
\hline Shower & $P=14.68 \times e^{-0.384\left[\text { day }^{-1}\right] \times t}(1<t<7)$ \\
\hline Heavy Rain & $P=18.46 \times e^{-0.208\left[\text { day }^{-1}\right] \times t}(1<t<14)$ \\
\hline
\end{tabular}

\subsection{Dispersion modelling}

The modelling system used for this study was CALPUFF (Version 6.42). This is a regional Langrangian puff model and can accommodate various effects such as spatial and temporal variability of the meteorology over a region, dry deposition and dispersion over spatially varying land surfaces. The main reason CALPUFF was used for this study is that it builds on a work done by Scorgie and Kornelius (2009), which not only reduced the resources required to quantify emission sources, but had also been shown to correlate reasonably well with measured $\mathrm{SO}_{2}, \mathrm{SO}_{4}, \mathrm{NO}, \mathrm{NO}_{2}$ and $\mathrm{NO}_{3}{ }^{-}$ambient concentrations as well as recorded and simulated wet, dry and total sulfur deposition rates for the Highveld.

\subsection{Highveld dispersion model and emission inventory}

The modelling domain was chosen to be large enough to include important pollutant sources and relevant water catchments on the Highveld. The south west corner of the domain is at $-27.398^{\circ}$ longitude and $-28.5644^{\circ}$ latitude and covers an area of $350 \mathrm{~km}$ (east-west) by $350 \mathrm{~km}$ (north-south). A receptor grid consisting of 70 cells by 70 cells with a resolution of $5 \mathrm{~km}$ was set up to investigate the spatial and temporal pollutant dispersion and deposition rates at ground level. 
Instead of collecting wind speed data at specified heights from upper air and surface weather stations, MM5 data (a prognostic wind field model that has been developed by Penn State University and the National Centre for Atmospheric Research (NCAR)) was used to generate the meteorological data (CALMET file).

An initial model run time from 1 January 2001 to 31 December 2001 was chosen. Reasons for the chosen runtime include:

- 2001 represents an average rainfall year.

- 2001 was originally chosen by Scorgie and Kornelius due to all emission and source data being available for that year.

- Published deposition monitoring data used for model verification was available for that time period (Scorgie and Kornelius 2009).

To include the effects of rain, a below average rainfall year (2003) and an above average rainfall (2010) year were selected as additional scenarios.

\subsubsection{Emission Sources}

Various $\mathrm{SO}_{x}$ and $\mathrm{NO}_{x}$ emission sources were inventoried by Scorgie and Kornelius (2009) and included the following:

- All large coal fired power generation located on the Highveld.

- From industries holding licenses under the Air Quality Act of 2004 or combustion and other chemical industrial emissions permits under the Atmospheric Pollution Prevention Act of 1965.

- Household coal, liquefied petroleum gas (LPG), paraffin and wood burning.

- Institutional and commercial (schools, hospitals and businesses) burning of coal, heavy fuel oil, wood and gas.

- Vehicle tailpipe emission from petrol and diesel vehicles.

- Biomass burning such as veld fires. 


\subsubsection{Chemical transformation and deposition modelling}

CALPUFF has several chemical transformation schemes which must be specified by the user to simulate the transformation processes. The RIVAD/ARM3 scheme was used to model the gas phase reactions. The reasons for the use of this scheme are:

- The scheme allowed for separate modelling of $\mathrm{NO}$ and $\mathrm{NO}_{2}$, whereas the standard MESOPUFF II scheme only models nitrogen compounds as NOx.

- The conversion of $\mathrm{NO}$ to $\mathrm{NO}_{2}, \mathrm{NO}_{2}$ to total $\mathrm{NO}_{3}{ }^{-}$and $\mathrm{SO}_{2}$ to $\mathrm{SO}_{4}^{-}$are done in equilibrium with gaseous $\mathrm{HNO}_{3}$ and ammonium nitrate aerosol.

- Daily $\mathrm{OH}^{-}$concentration variations can be approximated with user specified daily ozone data.

The above mentioned hourly varying ozone data was composed from data received from Eskom's Verkykkop, Elandsfontein, and Kendal 2 stations for the years of 2000/1.

Gas and particle dry deposition rates are predicted from atmospheric concentrations by a resistance deposition model within CALPUFF. To assist in dry deposition calculations site specific deposition velocities were input into CALPUFF by Scorgie and Kornelius. Hourly variations of seasonal average concentrations were specified for each of the following species: $\mathrm{SO}_{2}, \mathrm{NO}, \mathrm{NO}_{2}$ and $\mathrm{HNO}_{3}$.

Total sulfur deposition includes wet and dry deposition of gaseous $\mathrm{SO}_{2}$ and particulate $\mathrm{SO}_{4}^{-}$, while total nitrogen deposition includes the dry deposition of $\mathrm{NO}, \mathrm{NO}_{2}, \mathrm{HNO}_{3}, \mathrm{NO}_{3}^{-}$ and ammonium sulphate and the wet deposition of $\mathrm{HNO}_{3}, \mathrm{NO}_{3}{ }^{-}$and ammonium sulphate.

Gaseous $\mathrm{NH}_{3}$ and biogenic $\mathrm{NO}_{x}$ emission were not included in the original model of Scorgie and Kornelius and their results therefore under-predict the total $\mathrm{N}$ deposited on the Highveld. To account for the contribution of ammonium sulphate and ammonium nitrate it was assumed by Scorgie and Kornelius that $\mathrm{SO}_{4}{ }^{-}$and $\mathrm{NO}_{3}{ }^{-}$were completely neutralized by the $\mathrm{NH}_{4}{ }^{+}$. To calculate the amount of ammonium that is deposited due to 
the ammonium salts the following stoichiometric factors were applied to the $\mathrm{SO}_{4}{ }^{-}$and $\mathrm{NO}_{3}{ }^{-}$ fluxes predicted by CALPUFF.

$$
\begin{aligned}
& 0.292 \times \mathrm{SO}_{4}^{-} \\
& 0.226 \times \mathrm{NO}_{3}^{-}
\end{aligned}
$$

Important differences between the Scorgie and Kornelius model and the current model are:

- Instead of composing meteorological data from scratch the current model made use of MM5 data which included upper air, surface data and rainfall data

- All sources except biomass burning on the Highveld were included in the current model. In the original model biomass burning accounted only for $0.04 \%$ of $\mathrm{SO}_{2}$ emissions and $0.5 \%$ of $\mathrm{NO}_{x}$ emissions.

\subsubsection{Estimated Highveld biogenic NOx emissions}

Land use was sourced from the CALMET file set up for the CALPUFF simulations. The modelling domain is divided into smaller cells, each one representing the overall land use for that area. The $350 \times 350 \mathrm{~km}$ modelling domain was divided into 196 area sources. Each area source consists of 16 to 25 cells, $5 \times 5 \mathrm{~km}$ large and representing the overall type of land use for that area. The standard UTM coordinates became distorted over such a large area therefore the coordinate system used for this area (see Figure 2 below) is Lambert Conic Conformal (LCC) 


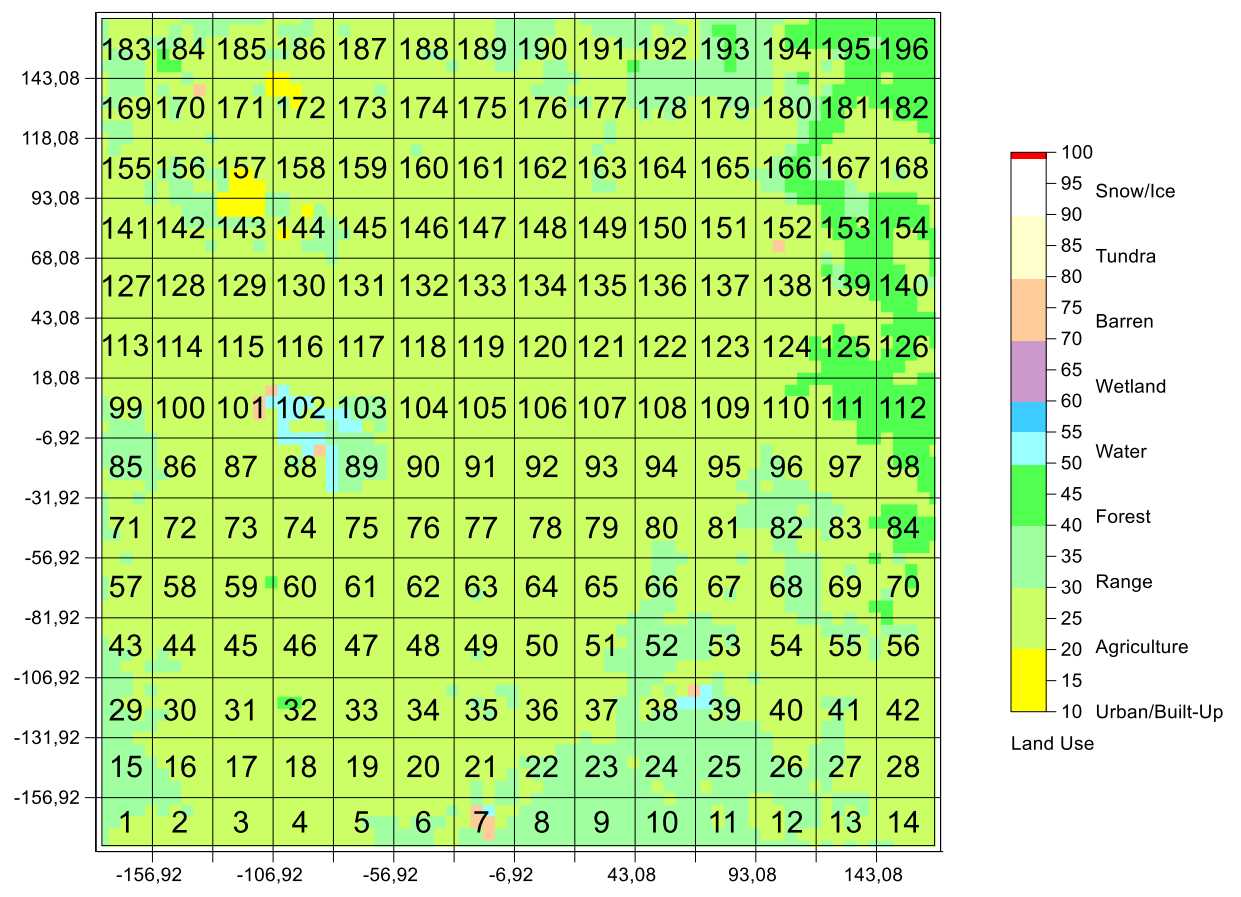

Fig 2: 196 defined area sources and land use for the Highveld (LCC coordinates)

Range land and agricultural land were assumed to be grasslands. The only other land use types that affected the biogenic calculation were the forest/plantations to the east of the modelling domain, main urban areas within the Gauteng province and some water bodies (mainly the Vaal dam in central Gauteng). Urban and barren land types were assumed to emit no biogenic $\mathrm{NO}_{\mathrm{x}}$. The values used for both grassland and forest/plantations are shown below in Table 6 below.

Table 6: Emission coefficients for the Highveld (Yienger and Levy 1995)

\begin{tabular}{|c|c|c|}
\hline Biome & Aw & Ad \\
\hline Grasslands & 0.36 & 2.65 \\
\hline Forest & 0.03 & 0.22 \\
\hline
\end{tabular}

Sourcing of ground level atmospheric temperature and rainfall rates for the duration of each of the three modelling periods (2001, 2003 and 2010) for each cell was done from CALMET as mentioned above. It should be noted that to create a CALMET file, MM5 
data is used as input and the rainfall data extracted from the CALMET file would be that predicted by the MM5 file. An average temperature and rainfall value for the entire area covered by each area source was extracted from CALMET for every hour for an entire year. The atmospheric ground level temperatures were then converted to soil temperatures by using the formulae in Table 1.

\subsubsection{Including biogenic NOx in CALPUFF}

For each defined area source an hourly NOx emission was calculated using equations 8 to 10 when the soil was wet and equations 11 to 12 when dry. From the rainfall rates, pulsing events were identified and emission rates calculated using equations 13 to 16 . Finally, for each of the 196 area sources the hourly NOx value for every hour for the entire year was then input into CALPUFF using a Buoyant Area Source Emissions File with Arbitrarily Varying Emissions (BAEMARB.DAT) file.

These emissions could then be included into the model to study the impact form biogenic emission on nitrogen deposition on the Highveld. This was done for each of the three modelling periods of 2001, 2010 and 2003.

Model limitations:

- Rainfall rates were extracted from the CALMET files generated for each of the three modelling periods. The MM5 data used to generate the CALMET files over predicted the rainfall rates somewhat; this means the predicted biogenic NOx emissions for each modelling period may also be over predicted.

- Canopy reduction was not considered.

\subsection{Waterberg Dispersion Model and Emission Inventory}

The Waterberg area is located within the Limpopo province within South Africa and is bordered to the west by Botswana. It is a much smaller area than the South African Highveld but also contains a large coal field, which is being mined primarily to supply 
adjacent coal fired power stations. The emission inventory for this area is based on previous work done by Liebenberg-Enslin et al. (2009).

\subsubsection{Summary of Waterberg sulfur and nitrogen emissions}

The Waterberg area largest emissions of $\mathrm{NOx}$ and $\mathrm{SO}_{2}$ are due to power generation. Emissions from household burning and vehicle tailpipe were excluded due to the very small amounts of $\mathrm{SO}_{2}$ and $\mathrm{NOx}$ these sources contribute to the total emission rates (Table 7).

Table 7: Total $\mathrm{SO}_{2}$ and $\mathrm{NO}_{x}$ emissions calculated for the Waterberg area

\begin{tabular}{|c|c|c|c|c|}
\hline Source & $\mathrm{SO}_{2}$ (tpa) & $\%$ of total $\mathrm{SO}_{2}$ & NOx $($ tpa) & $\%$ of total $\mathrm{NO}_{\mathrm{x}}$ \\
\hline \multirow[t]{2}{*}{ Power Generation } & $309262(a)$ & $38.65(a)$ & $67592(\mathrm{a})$ & $42.31(\mathrm{a})$ \\
\hline & $490872(b)$ & $61.35(b)$ & 92038 (b) & 57.62 (b) \\
\hline Household Burning & 0.06 & 0.00001 & 0.63 & 0.0004 \\
\hline Tailpipe Emissions & 2.6 & 0.0003 & 115 & 0.07 \\
\hline Total & 800136.66 & & 159745.63 & \\
\hline \multicolumn{5}{|l|}{ Notes: } \\
\hline \multicolumn{5}{|c|}{ (b) Medupi } \\
\hline
\end{tabular}

\subsubsection{Estimated Waterberg $\mathrm{NO}_{x}$ emissions}

25 area sources were defined for the Waterberg area, each consisting from 475 to 520 cells of $1 \mathrm{~km} \times 1 \mathrm{~km}$. Each cell has land use type attached to it. Standard UTM coordinates were used for this area and is also used in Figure 3.

Here a distinction was made between rangeland and agricultural land. Grassland emission coefficients were again assigned to the agricultural land use type for the same reasons mentioned above. The rangeland land use type was treated as savanna biome. For this biome emission coefficients were calculated using the same method as Yienger and Levy (1995). Temperature and flux were applied asper equations 8, 9, 10 and 11 to 
calculate an Aw/D value. These values were then linearized and from this an average $A w / D$ coefficient was calculated. This process is summarized below in Table 8 and Table 9.

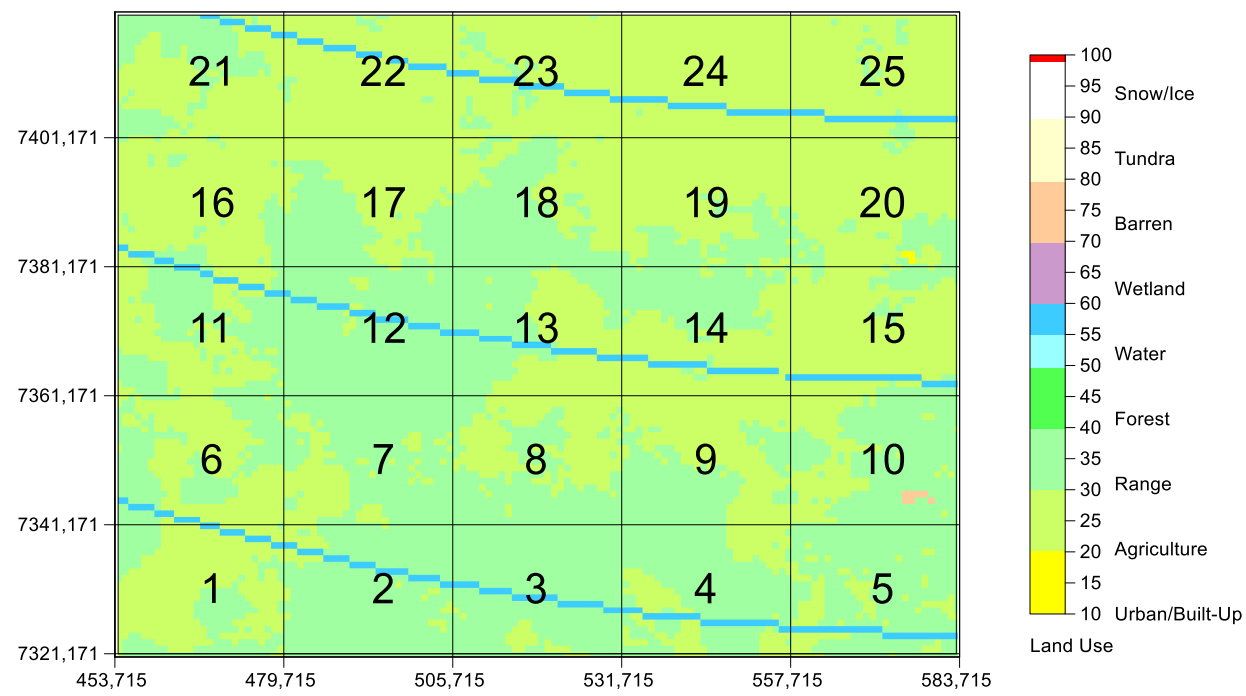

Fig 3: 25 defined area sources and land use for the Waterberg area (UTM coordinates)

(Isopleth bars are an artefact generated by the mesh factor used in CALMET file generation) 
Table 8: Wet Savanna Biome emission coefficient calculation

\begin{tabular}{|c|c|c|c|c|c|c|}
\hline $\begin{array}{c}\text { Temperature } \\
\text { Interval }\end{array}$ & $\begin{array}{c}\text { Flux } \\
\text { (ng NO/m²s) }\end{array}$ & $\begin{array}{c}\text { Flux } \\
\text { (ng N/m²s) }\end{array}$ & $\begin{array}{c}\mathrm{T} \\
\left({ }^{\circ} \mathrm{C}\right)\end{array}$ & $A_{w}$ & $\ln A_{w}$ & Reference \\
\hline $10-30^{\circ} \mathrm{C}$ & $\begin{array}{c}2,4 \\
1,3 \\
1,7 \\
1,5 \\
- \\
-\end{array}$ & $\begin{array}{c}20 \\
1,128 \\
0,611 \\
0,799 \\
0,705 \\
13,026 \\
10,812\end{array}$ & $\begin{array}{l}28 \\
25 \\
25 \\
25 \\
25 \\
25 \\
25 \\
25\end{array}$ & $\begin{array}{c}1,18262 \\
0,090306 \\
0,048916 \\
0,063967 \\
0,056441 \\
1,04284 \\
0,86559\end{array}$ & $\begin{array}{r}0,167732 \\
-2,40455 \\
-3,01766 \\
-2,74939 \\
-2,87456 \\
0,041947 \\
-0,14434\end{array}$ & $\begin{array}{c}\text { Scholes et al. } \\
1997 \\
\text { Feig et al. } \\
2008\end{array}$ \\
\hline$>30{ }^{\circ} \mathrm{C}$ & $\begin{array}{c}3,5 \\
3 \\
3,5 \\
-\end{array}$ & $\begin{array}{c}1,645 \\
1,41 \\
1,645 \\
45\end{array}$ & $\begin{array}{l}35 \\
35 \\
35 \\
41\end{array}$ & $\begin{array}{l}0,074875 \\
0,064178 \\
0,074875 \\
2,048248\end{array}$ & $\begin{array}{l}-2,59194 \\
-2,74609 \\
-2,59194 \\
0,716985\end{array}$ & $\begin{array}{c}\text { Feig et al. } \\
2008\end{array}$ \\
\hline Average & \multicolumn{6}{|c|}{-1.65398} \\
\hline $\begin{array}{c}A_{w} \\
\text { Savanna }\end{array}$ & & & \multicolumn{4}{|c|}{0,191287} \\
\hline
\end{tabular}

Table 9: Dry Savanna Biome emission coefficient calculation

\begin{tabular}{|c|c|c|c|c|}
\hline $\begin{array}{c}\text { Temperature } \\
\text { Interval }\end{array}$ & $\begin{array}{c}\text { Flux }(\mathbf{n g} \\
\left.\mathbf{N} / \mathbf{m}^{2} \mathbf{S}\right)\end{array}$ & $\mathbf{T}\left({ }^{\circ} \mathbf{C}\right)$ & $\mathbf{A}_{\mathbf{D}}$ & Reference \\
\hline $0-30^{\circ} \mathbf{C}$ & 2 & 28 & 2,142857 & Scholes et al. 1997 \\
\hline
\end{tabular}

Rainfall for the Waterberg could not be sourced from the CALMET file as was the case for the Highveld. In this case, yearly rainfall for Lephalale as supplied by the South African Weather Services was used. Temperature for each area source was sourced from CALMET.

As for the Highveld, an hourly NOx rate was calculated for each of the 25 area sources defined above for each day for the entire modelling period of 2006.

Model limitations:

- Rainfall used to predict NOx represents only a single point and does not consider the spatial rainfall pattern for this the area. 
- Canopy reduction was not considered.

\section{RESULTS AND DISCUSSION}

\subsection{Estimated $\mathrm{NO}_{\mathrm{x}}$ emissions for the South African Highveld.}

The calculated total annual biogenic $\mathrm{NO}_{x}$ for the entire modelling domain for the three modelling periods are shown below in Table 10 are compared to the other NOx sources from the 2001 emission inventory. Biomass burning values from the previous Scorgie and Kornelius (2009) study are included for comparison.

The biogenic $\mathrm{NO}_{x}$ emitted made up $3.96 \%, 4.14 \%$ and $3.45 \%$ of total released $\mathrm{NO}_{\mathrm{x}}$ for 2001, 2003 and 2010 respectively. This is significantly more than is released by household fuel burning, small industrial sources and biomass burning.

Table 10: Total Highveld NOx emissions for 2001, 2003 and 2010 compared to NOx emissions from the 2001 emission inventory.

\begin{tabular}{|c|c|c|c|c|c|c|}
\hline Year & \multicolumn{2}{|c|}{2001} & \multicolumn{2}{|c|}{2003} & \multicolumn{2}{|c|}{2010} \\
\hline $\begin{array}{l}\text { Source } \\
\text { group }\end{array}$ & $\begin{array}{l}\mathrm{NO}_{x} \\
\text { (tpa) }\end{array}$ & $\begin{array}{c}\% \text { of total } \\
\mathrm{NO}_{\mathrm{x}} \\
\text { emissions }\end{array}$ & $\begin{array}{l}\mathrm{NO}_{x} \\
\text { (tpa) }\end{array}$ & $\begin{array}{l}\% \text { of total } \\
\mathrm{NO}_{x} \\
\text { emissions }\end{array}$ & $\begin{array}{l}\mathrm{NO}_{x} \\
\text { (tpa) }\end{array}$ & $\begin{array}{c}\% \text { of total } \\
\mathrm{NO}_{\mathrm{x}} \\
\text { emissions }\end{array}$ \\
\hline $\begin{array}{c}\text { Major } \\
\text { sources(a) }\end{array}$ & 526345 & 73.83 & 526345 & 73.7 & 526345 & 74.22 \\
\hline $\begin{array}{c}\text { Other } \\
\text { industrial } \\
\text { sources }\end{array}$ & 4099 & 0.57 & 4099 & 0.57 & 4099 & 0.58 \\
\hline $\begin{array}{l}\text { Household } \\
\text { fuel burning }\end{array}$ & 3449 & 0.48 & 3449 & 0.48 & 3449 & 0.49 \\
\hline $\begin{array}{c}\text { Vehicle } \\
\text { exhaust } \\
\text { emissions }\end{array}$ & 147577 & 20.7 & 147577 & 20.66 & 147577 & 20.81 \\
\hline $\begin{array}{c}\text { Biomass } \\
\text { burning } \\
\text { (wildfires) } \\
\end{array}$ & 3204 & 0.45 & 3204 & 0.45 & 3204 & 0.45 \\
\hline Biogenic $N O_{x}$ & 28249 & 3.96 & 29540 & 4.14 & 24475 & 3.45 \\
\hline
\end{tabular}

(a) Mainly coal fired power stations 


\subsection{Temporal Biogenic NO $x$ Emission Patterns}

The monthly average $\mathrm{NO}_{x}$ emission rate calculated for the $25 \mathrm{~km} \times 25 \mathrm{~km}$ blocks ranges from:

- $2.11-7.73 \mathrm{~g} \mathrm{~s}^{-1}$, with an annual average rate of $4.53 \mathrm{~g} \mathrm{~s}^{-1}$ for 2001 .

- $1.94-9.00 \mathrm{~g} \mathrm{~s}^{-1}$ with an annual average rate of $3.96 \mathrm{~g} \mathrm{~s}^{-1}$ for 2010 .

- $2.11-7.62 \mathrm{~g} \mathrm{~s}^{-1}$ with an annual average rate of $4.78 \mathrm{~g} \mathrm{~s}^{-1}$ for 2003.

The monthly $\mathrm{NO}_{x}$ emitted is shown for each modelled year in Figures 4 to 6 below. The highest amounts of $\mathrm{NO}_{x}$ occur in the spring and autumn months. These are the months when the largest $\mathrm{NO}_{x}$ pulses are releases on the Highveld. These time periods produce conditions when the soil remains dry for long enough periods so that soil nutrients build up, and then for large enough rainstorms to wet the soil quickly. When the soil moisture content remains constant (wet or dry) no pulses occur.

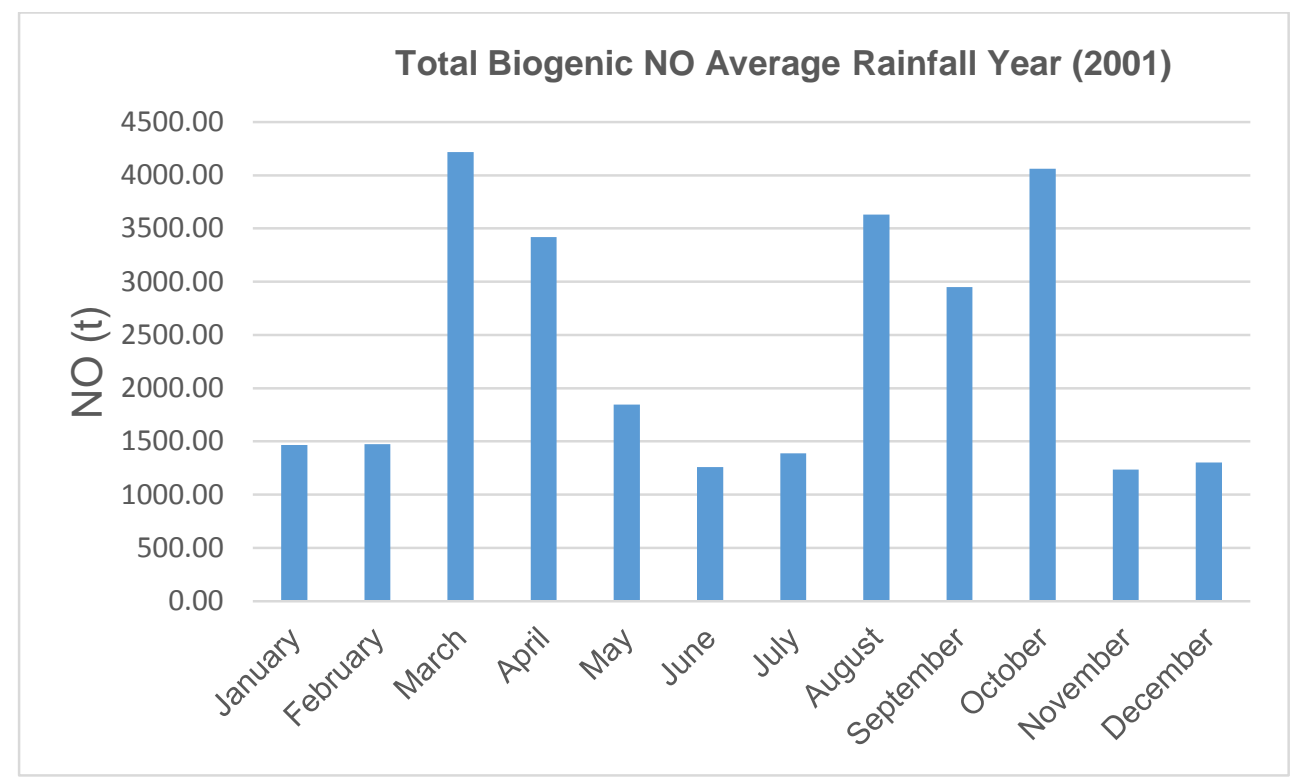

Fig 4: Seasonal biogenic emissions for 2001 


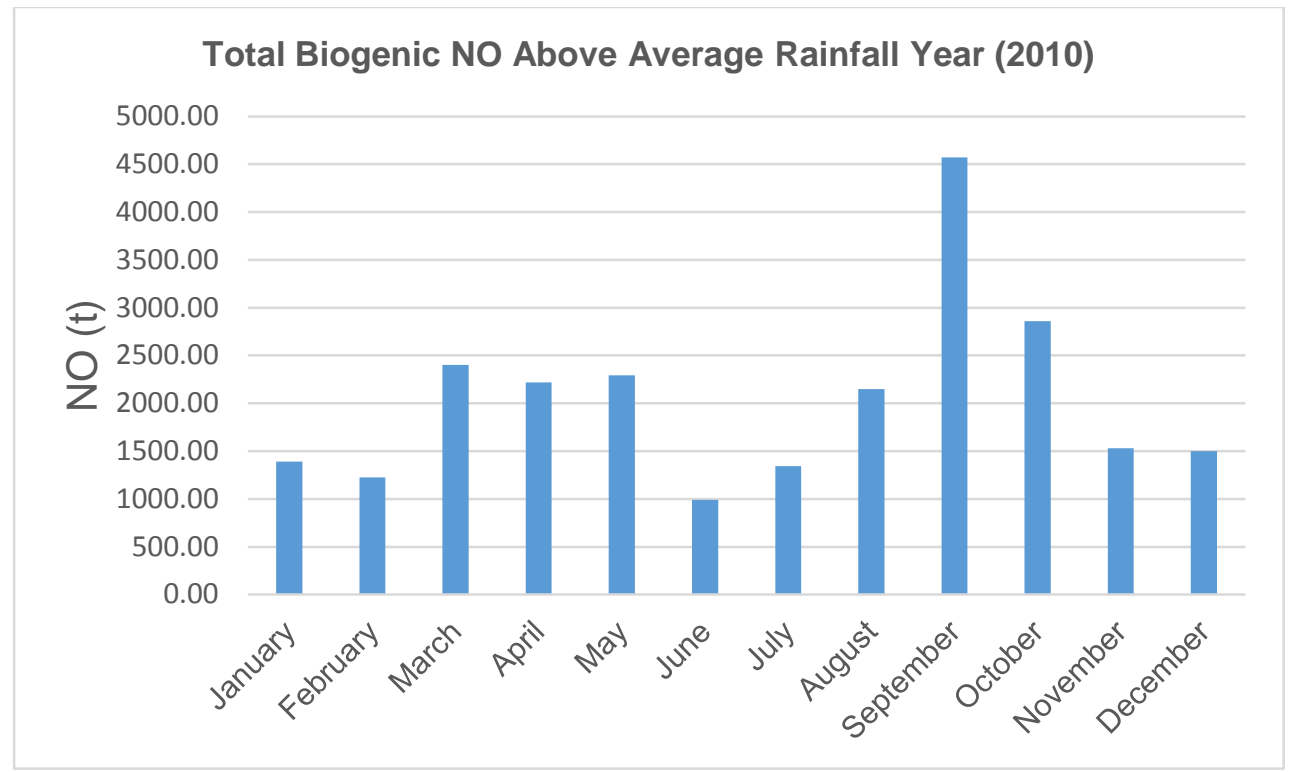

Fig 5: Seasonal biogenic emissions for 2010

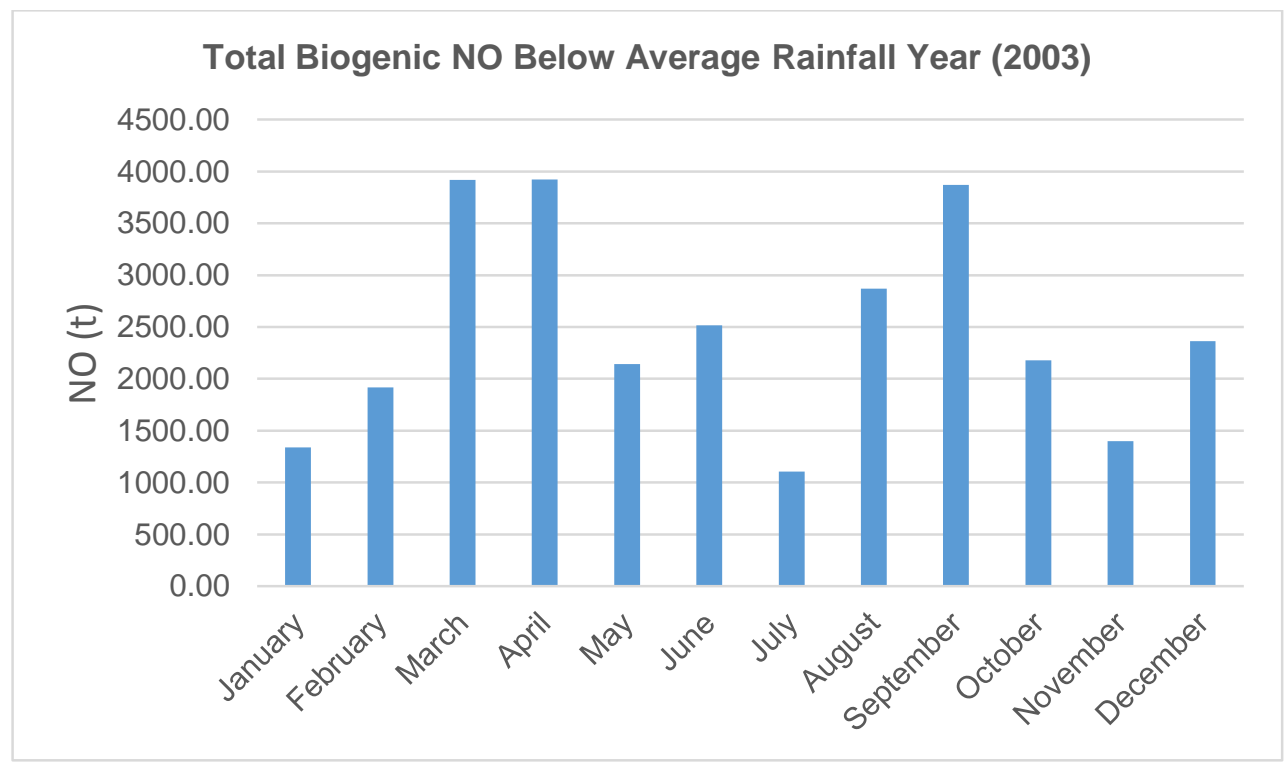

Fig 6: Seasonal biogenic emissions for 2003 


\subsection{Contribution of biogenic $\mathrm{NO}_{x}$ emissions on the nitrogen concentration over- and deposition on the South African Highveld.}

The effect of the biogenic $\mathrm{NO}_{x}$ emission on ambient nitrogen based gases and on nitrogen deposition at selected receptor locations is shown in Table 11. Main trends are:

- Ambient annual NO concentration contribution varies between $2.59 \%$ and $35.37 \%$.

- Ambient annual $\mathrm{NO}_{2}$ concentration contribution varies between $5.21 \%$ and 9.25 $\%$.

- Dry nitrogen deposition rates have been affected the most. Biogenic NOx added between $1.69-6.19 \%$.

- Wet deposition rates were affected very little due to the secondary nature of the ammonium salts formed in the atmosphere $(0.13 \%$ to $0.75 \%)$.

- Total contribution to nitrogen deposition rates ranged from $0.32 \%$ to $1.77 \%$.

Dry $\mathrm{N}$ deposition rates were the most affected by biogenic NOx emissions. This is because the wet $\mathrm{N}$ rates are generally much higher than dry $\mathrm{N}$ rates. Comparing the predicted wet $\mathrm{N}$ and dry $\mathrm{N}$ deposition rates due to biogenic $\mathrm{NOx}$ at each receptor point the wet $\mathrm{N}$ rates are from 1.14 to 2.08 times larger. Also, during dry periods conditions are favorable for dry deposition after a short rain spell. Wetted surface due to any rainfall would enhance the removal rates due to dry deposition. 
Table 11: Percentage contribution of biogenic $\mathrm{NO}_{\mathrm{x}}$ emissions to nitrogen deposition on the South African Highveld at specific receptor locations.

\begin{tabular}{|c|c|c|c|c|c|}
\hline $\begin{array}{c}\text { Modelled } \\
\text { (2001) }\end{array}$ & $\begin{array}{c}\text { \% Biogenic } \\
\text { NO }\end{array}$ & $\begin{array}{c}\text { \% Biogenic } \\
\text { NO}_{2}\end{array}$ & $\begin{array}{c}\text { \% Biogenic } \\
\text { Dry N }\end{array}$ & $\begin{array}{c}\text { \% Biogenic } \\
\text { Wet N }\end{array}$ & $\begin{array}{c}\text { \% Biogenic } \\
\text { Total N }\end{array}$ \\
\hline Verkykkop & 17.03 & 5.28 & 6.19 & 0.71 & 1.77 \\
\hline Elandsfontein & 2.59 & 5.23 & 3.19 & 0.75 & 1.43 \\
\hline Kendal2 & 5.25 & 9.25 & 1.69 & 0.13 & 0.32 \\
\hline Leandra & 2.39 & 8.78 & 1.71 & 0.39 & 0.73 \\
\hline Majuba1 & 12.24 & 5.13 & 5.24 & 0.7 & 1.54 \\
\hline Palmer & 35.37 & 7.21 & 2.04 & 0.73 & 1.12 \\
\hline Amersfoort & 10.65 & 5.21 & 4.91 & 0.68 & 1.42 \\
\hline
\end{tabular}

\subsection{Predicted Highveld sulfur and nitrogen deposition}

\subsubsection{Average rainfall base case spatial results}

Annual average ambient $\mathrm{SO}_{2}$ concentration peaks on the central Highveld (up to $15 \mu \mathrm{g} / \mathrm{m}^{3}$ between Secunda, Bethal and Emalahleni), with smaller isolated areas of up to $30 \mu \mathrm{g} / \mathrm{m}^{3}$ scattered across this region. This is because most of the coal-fired power stations (Matla, Kriel, Duvha and Kendal) are located within this area as well as major sources such as the Sasol complex at Secunda and Highveld Steel near eMalahleni. A secondary peak is observed over the Vaal Triangle (up to $15 \mathrm{\mu g} \mathrm{m}^{-3}$ ) due to emissions from the steel works near Vanderbijlperk, Lethabo power station and the petrochemical complex near Sasolburg.

Annual average ambient sulfate concentrations $\left(1.5 \mathrm{\mu g} \mathrm{m}^{-3}\right)$ are spatially offset from the $\mathrm{SO}_{2}$ pattern described above. This is due to the secondary nature of sulfate particulate. A highly localised peak was predicted to the west of Emalahleni of up to and exceeding $2 \mu \mathrm{g} \mathrm{m} \mathrm{m}^{-3}$.

Annual average ambient $\mathrm{NO}_{2}$ concentrations over the central Highveld were predicted up to $3 \mu \mathrm{g} \mathrm{m}^{-3}$ with scattered locations of up $5 \mu \mathrm{g} \mathrm{m}^{-3}$ and higher. Concentrations up to $6 \mu \mathrm{g}$ 
$\mathrm{m}^{-3}$ were predicted to be centred over the Vaal Triangle, with lower $\mathrm{NO}_{2}$ concentration of $3 \mu \mathrm{g} \mathrm{m}^{-3}$ stretching from the Vaal Triangle to the south Gauteng metropolitan areas and a small area located close to the Tshwane metropolitan area, which is due to emissions from motor vehicles and household combustion sources.

Annual average ambient nitrate peak values were predicted to be spatially offset from the sources due the secondary nature of the pollutant. A $5 \mu \mathrm{g} \mathrm{m}^{-3}$ nitrate isopleth stretches between Emalahleni and the Vaal Triangle.

Annual average total sulfur deposition peaks $\left(20 \mathrm{~kg} \mathrm{ha}^{-1} \mathrm{yr}^{-1}\right)$ occur over the central Highveld between Emalahleni, Standerton and Ermelo, with scattered areas of up to 35 $\mathrm{kg} \mathrm{ha}^{-1} \mathrm{yr}^{-1}$ close to Bethal and Secunda. A second elevated area (between $10 \mathrm{~kg} \mathrm{ha}^{-1} \mathrm{yr}^{-1}$ and $20 \mathrm{~kg} \mathrm{ha}^{-1} \mathrm{yr}^{-1}$ ) east of the Vaal triangle was also predicted. Most of the Highveld was predicted to receive between $5 \mathrm{~kg} \mathrm{ha}^{-1} \mathrm{yr}^{-1}$ and $10 \mathrm{~kg} \mathrm{ha}^{-1} \mathrm{yr}^{-1}$ sulfur.

Total annual wet $\mathrm{S}$ deposition had a very similar pattern to the total $\mathrm{S}$ deposition described above. Wet $\mathrm{S}$ deposition was predicted to range between $20 \mathrm{~kg} \mathrm{ha}^{-1} \mathrm{yr}^{-1}$ and $30 \mathrm{~kg} \mathrm{ha}^{-1} \mathrm{yr}^{-}$ ${ }^{1}$ close to Bethal and Secunda. A very localized area of wet $S\left(>10 \mathrm{~kg} \mathrm{ha}^{-1} \mathrm{yr}^{-1}\right)$ was predicted over the Vaal triangle. Total annual dry $S$ deposition peaked just west of Emalahleni ( $\left.>10 \mathrm{~kg} \mathrm{ha}^{-1} \mathrm{yr}^{-1}\right)$ with lower peak over the Vaal triangle (> $\left.5 \mathrm{~kg} \mathrm{ha}^{-1} \mathrm{yr}^{-1}\right)$.

Total annual nitrogen deposition peaks (>10 $\mathrm{kg} \mathrm{ha}^{-1} \mathrm{yr}^{-1}$ ) just west of the central Highveld, but stretches from Emalahleni to west of Standerton. Highly localized total $\mathrm{N}$ deposition is observed just south of the Vaal Triangle $\left(>10 \mathrm{~kg} \mathrm{ha}^{-1} \mathrm{yr}^{-1}\right)$. As is the case for $S$ deposition, total wet $\mathrm{N}$ deposition follows a similar spatial deposition pattern to the total $\mathrm{N}$ deposition due to large part wet $\mathrm{N}$ deposition makes up of the total $\mathrm{N}$ deposited on the Highveld. Wet $\mathrm{N}$ peaks from $6 \mathrm{~kg} \mathrm{ha}^{-1} \mathrm{yr}^{-1}$ to $9 \mathrm{~kg} / \mathrm{ha} / \mathrm{annum}$ just west of the central Highveld. In this case, no second peak is predicted over the Vaal triangle. Total dry N deposition (up to $5 \mathrm{~kg} \mathrm{ha}^{-1} \mathrm{yr}^{-1}$ ) is centered on the Vaal Triangle and an area stretching between Emalahleni, Secunda and Johannesburg with isopleths ranging from $3 \mathrm{~kg} \mathrm{ha}^{-1} \mathrm{yr}^{-}$ ${ }^{1}$ to $5 \mathrm{~kg} \mathrm{ha}^{-1} \mathrm{yr}^{-1}$ (see Figure 7 and 8 below). 


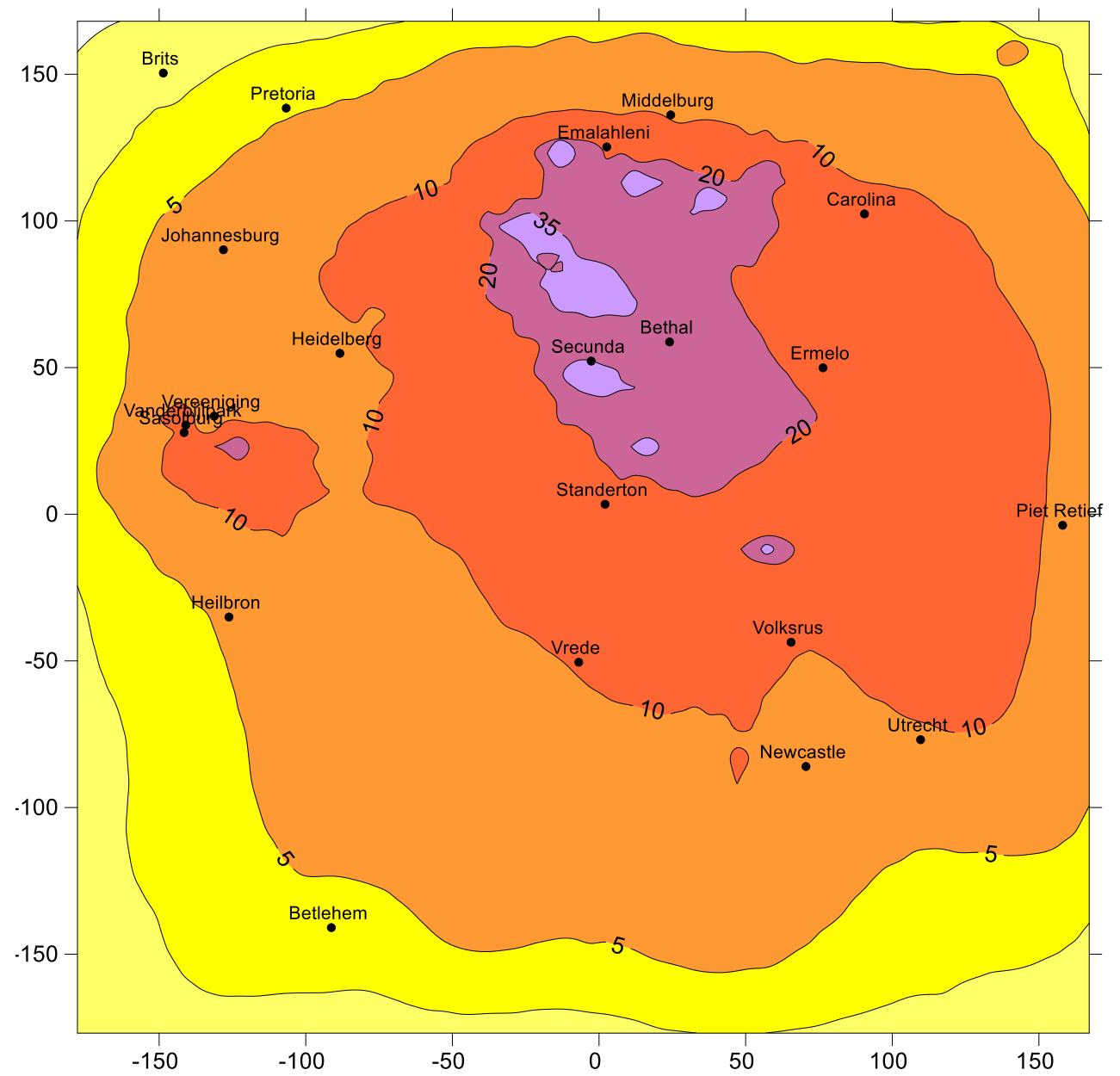

Fig 7: Monthly total NO emissions for 2006 


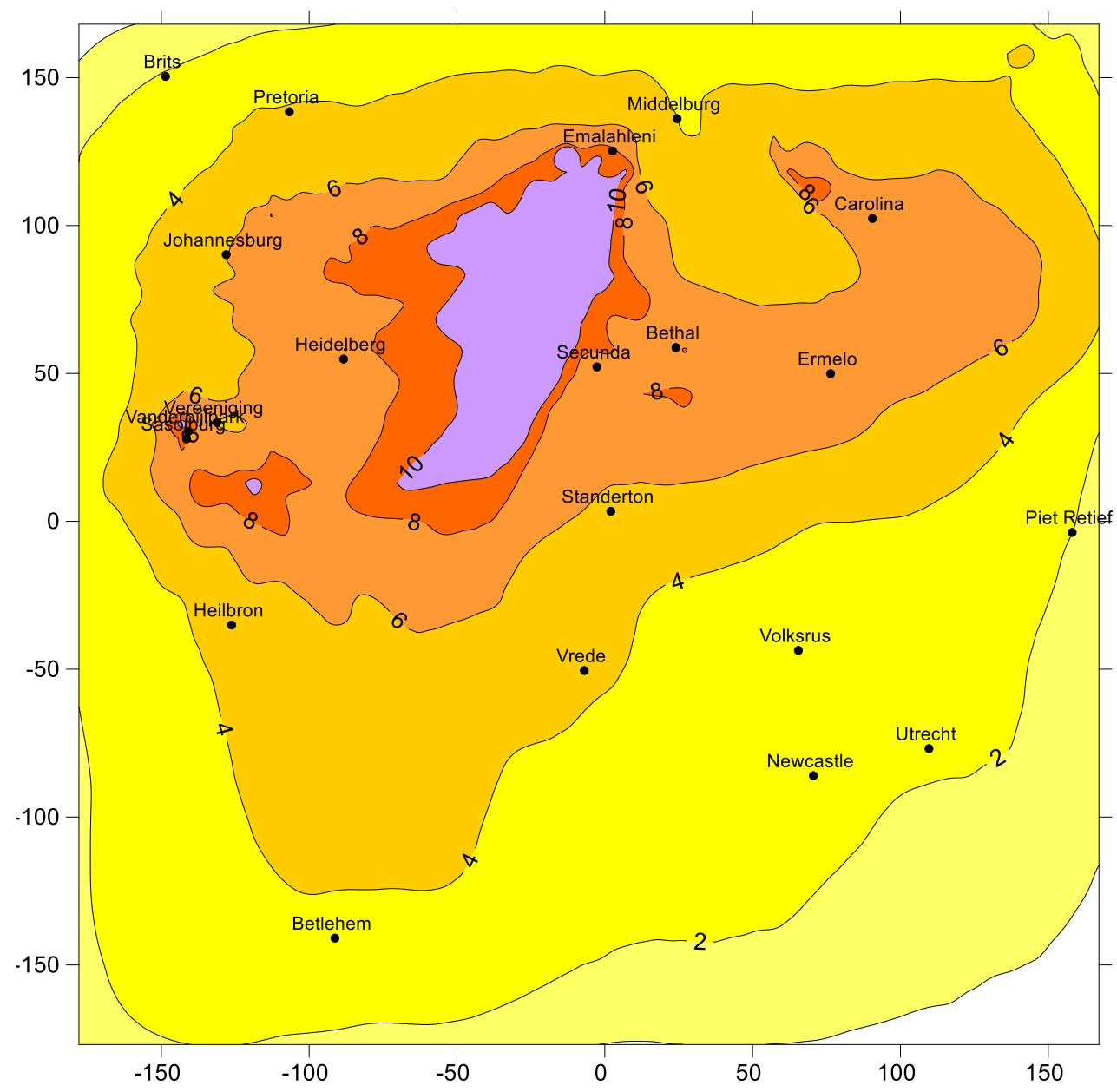

Fig 8: Predicted total annual sulfur deposition $\left(\mathrm{kg} \mathrm{ha}^{-1} \mathrm{yr}^{-1}\right)$, average rainfall year 2001

\subsubsection{Above average rainfall year (2010) spatial results}

The general spatial patterns predicted for 2010 appear very similar to those for 2001, with nitrogen and sulfur deposition peaking over the Highveld and the Vaal Triangle, but with the higher and spatially changing rainfall patterns there are some noticeable differences.

For total $S$ deposition, larger areas were predicted within the 10 and $20 \mathrm{~kg} \mathrm{ha}^{-1} \mathrm{yr}^{-1}$ isopleths. The $10 \mathrm{~kg} \mathrm{ha}^{-1} \mathrm{yr}^{-1}$ isopleth was predicted to be larger for dry $\mathrm{S}$ deposition, and 
stretches from Emalahleni to just outside Bethal. For wet $\mathrm{S}$ deposition, the $20 \mathrm{~kg} \mathrm{ha}^{-1} \mathrm{yr}^{-1}$ isopleth was predicted to be larger and covers an area from Emalahleni to close to Standerton.

All $\mathrm{N}$ spatial deposition plots (total, wet and dry) showed a third peak $\mathrm{N}$ deposition area to the east. This area was just outside Carolina and were most likely due to emissions from the nearby Hendrina and Arnot coal-fired power stations. Total $\mathrm{N}$ deposition was predicted to have an $8 \mathrm{~kg} \mathrm{ha}^{-1} \mathrm{yr}^{-1}$ isopleth similar in size to that predicted in 2001, but this one encompasses both Bethal and Secunda. In this case the $15 \mathrm{~kg} \mathrm{ha}^{-1} \mathrm{yr}^{-1}$ isopleth could also be clearly identified, which was not the case for 2001. For the dry $\mathrm{N}$ deposition, it was predicted that the $6 \mathrm{~kg} \mathrm{ha}^{-1} \mathrm{yr}^{-1}$ isopleth covers a larger area than for 2001 and stretched from the central Highveld to Carolina (see Figure 9 and 10 below).

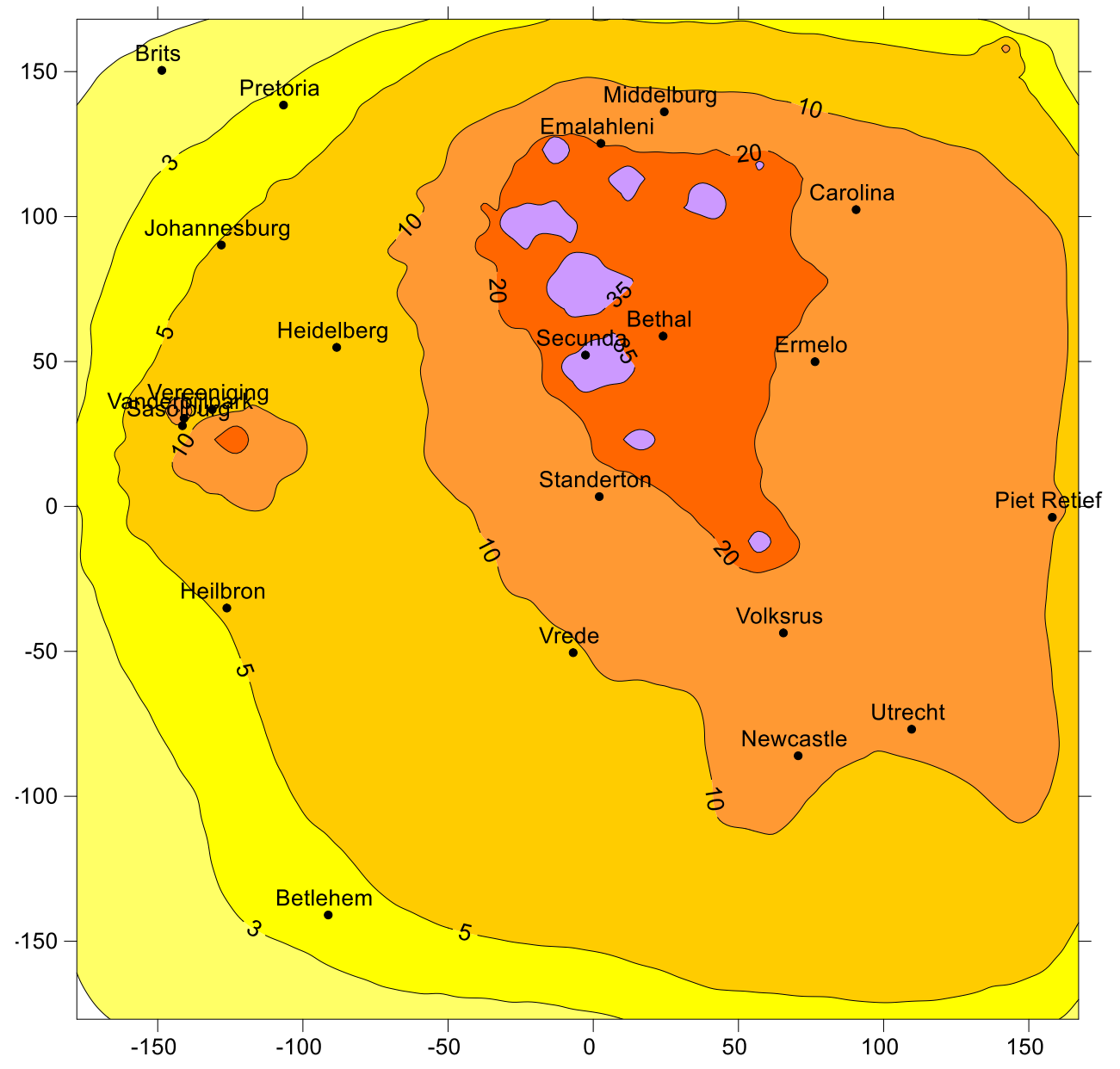


Fig 9: Predicted total annual nitrogen deposition $\left(\mathrm{kg} \mathrm{ha}^{-1} \mathrm{yr}^{-1}\right)$, average rainfall year 2001

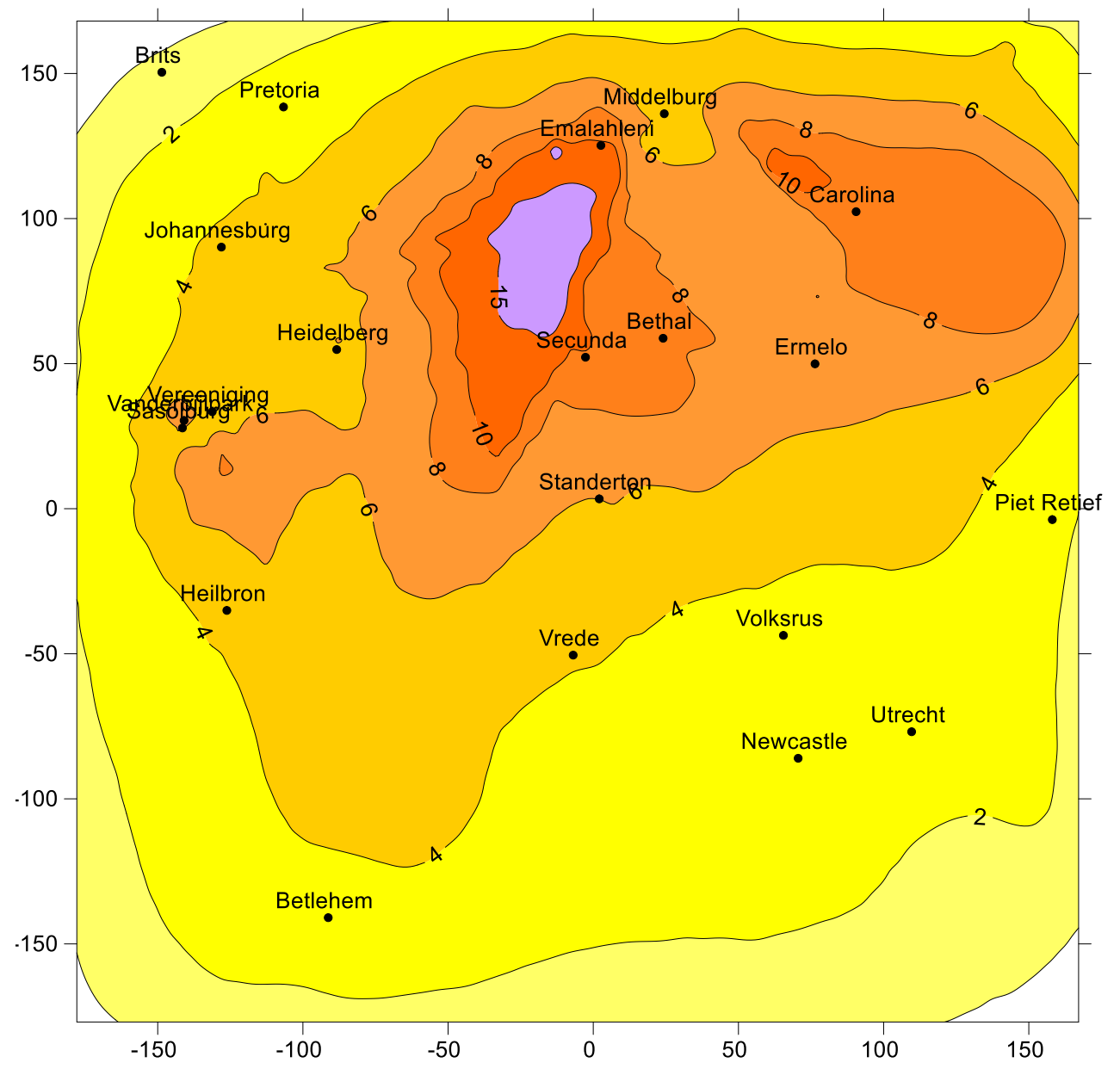

Fig 10: Predicted total annual sulfur deposition $\left(\mathrm{kg} \mathrm{ha}^{-1} \mathrm{yr}^{-1}\right)$, above average rainfall year 2010

\subsubsection{Below Average Rainfall (2003) Year Spatial Results}

For total S deposition, the $35 \mathrm{~kg} \mathrm{ha}^{-1} \mathrm{yr}^{-1}$ isopleth over the central Highveld was predicted to be much smaller than for 2001. Similarly, the wet $S$ deposition $20 \mathrm{~kg} \mathrm{ha}^{-1} \mathrm{yr}^{-1}$ isopleth was predicted to be concentrated around isolated areas rather than covering one large 
area as was predicted for wet S in 2001. Rainfall was lowest for this scenario, which would explain the smaller area these isopleths cover (see Figure 11 and 12 below).

The $10 \mathrm{~kg} \mathrm{ha}^{-1} \mathrm{yr}^{-1}$ isopleth predicted for dry $\mathrm{S}$ deposition covers a larger area than for both 2001 and 2010 and stretches from Emalahleni to an area close to Bethal and Secunda. The reason for this could be that during a drier period less atmospheric $\mathrm{SO}_{2}$ is removed through wet removal processes, which leaves dry removal as the only pathway through which atmospheric $\mathrm{SO}_{2}$ is removed from the atmosphere. The annual ambient average $\mathrm{SO}_{2}$ concentration were predicted to have a very similar spatial pattern to the total dry S deposition plot.

The total nitrogen deposition isopleth predicted also covered smaller areas than the plots predicted for 2001 and 2010.

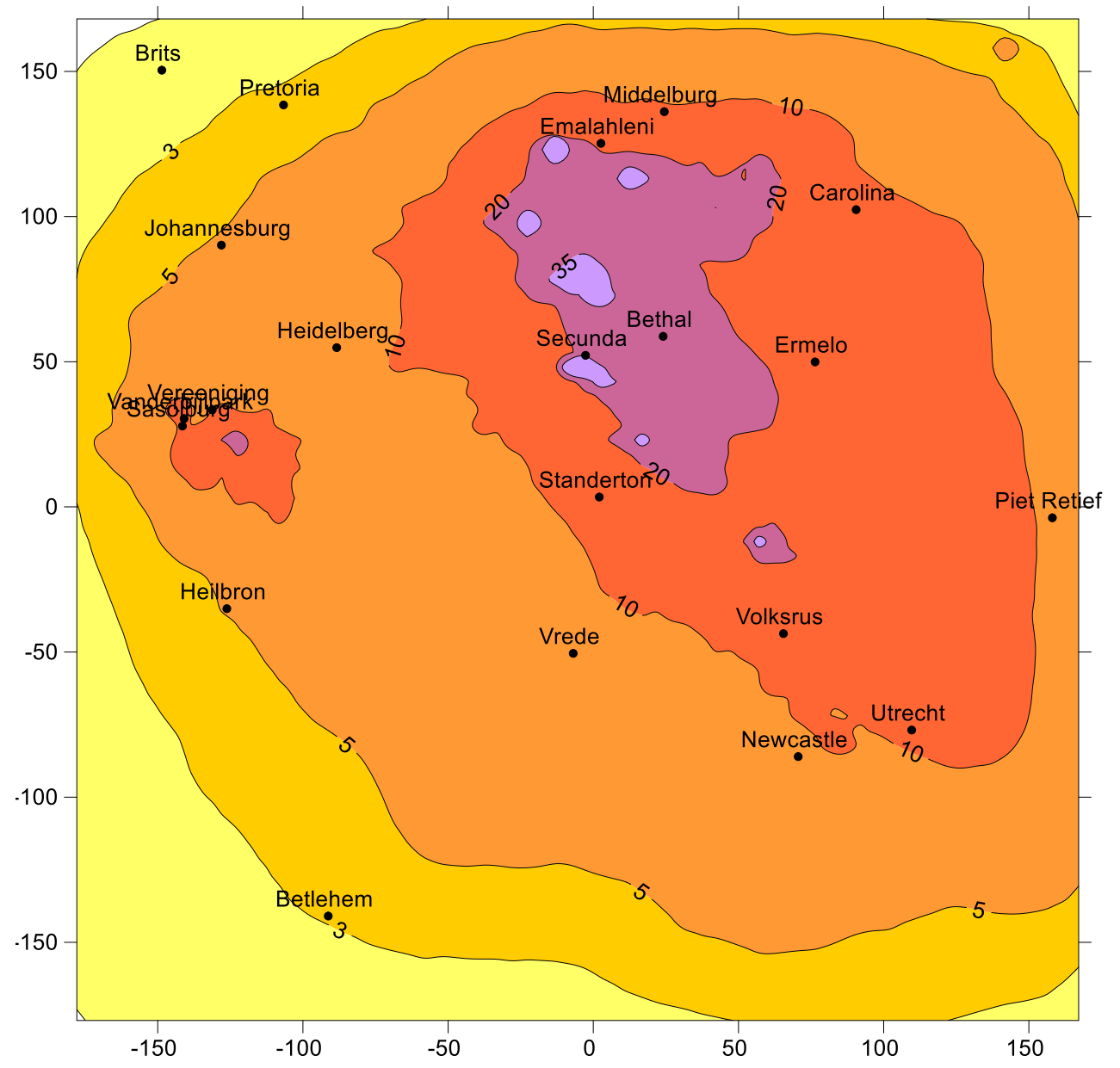


Fig 11: Predicted total annual nitrogen deposition $\left(\mathrm{kg} \mathrm{ha}^{-1} \mathrm{yr}^{-1}\right)$, above average rainfall year 2010

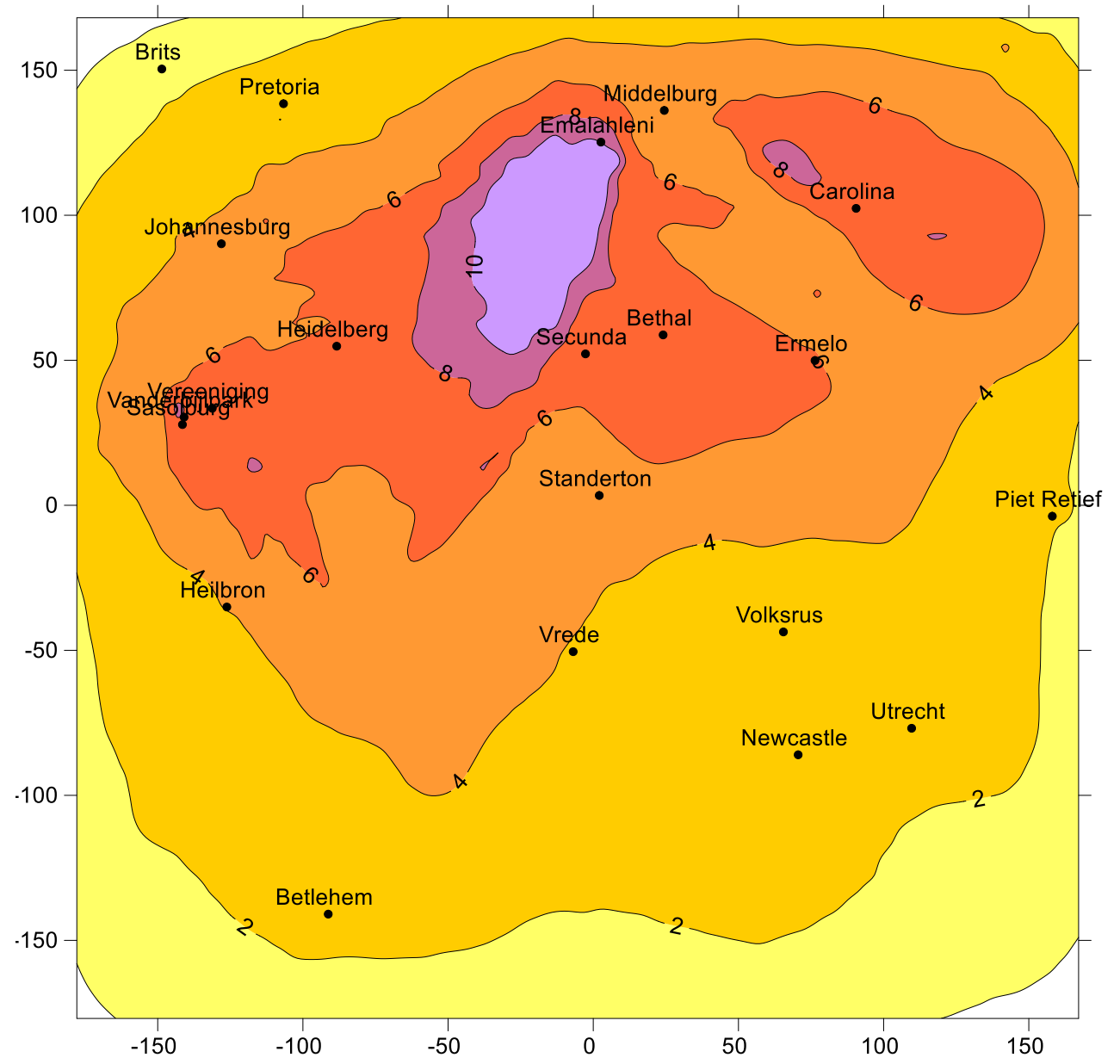

Fig 12: Predicted total annual sulfur deposition $\left(\mathrm{kg} \mathrm{ha}^{-1} \mathrm{yr}^{-1}\right)$, below average rainfall year 2003

\subsection{Waterberg Biogenic NOx emissions}

Biogenic emissions are only $2.3 \%$ of total $\mathrm{NO}_{\mathrm{x}}$ emissions for the Waterberg area. The modelling domain is much smaller than the domain used for the Highveld. Rainfall for this area is also much less. 
The main $\mathrm{NO}_{x}$ emissions, in total comprising $98 \%$ of emissions, are from Matimba and Medupi power stations. Because of these large NOx emissions from these power stations the biogenic $\mathrm{NO} x$ will have very little effect on $\mathrm{N}$ deposition within the area. The NOx emissions for this area are summarized in Table 12.

Table 12: Total NOx emissions for the Waterberg

\begin{tabular}{|c|c|c|}
\hline Source & NO $_{\mathbf{x}}$ (tpa) & $\begin{array}{c}\text { \% of total } \\
\text { NOx } \\
\text { emissions }\end{array}$ \\
\hline Power Generation & 159630 & 97.65 \\
\hline Household Burning & 0.63 & 0.00039 \\
\hline Tailpipe Emissions & 115 & 0.07035 \\
\hline Biogenic Emissions & 3721 & 2.28 \\
\hline Total & 163466.63 & \\
\hline
\end{tabular}

The different rainfall patterns suggest that the highest biogenic NOx emission rates and emission amounts occur during the summer months when soil moisture conditions are conducive to pulse events. The lowest emissions occur during winter when the soil moisture remains constant. The monthly emission rates and NOx amounts are shown in Figure 13 below.

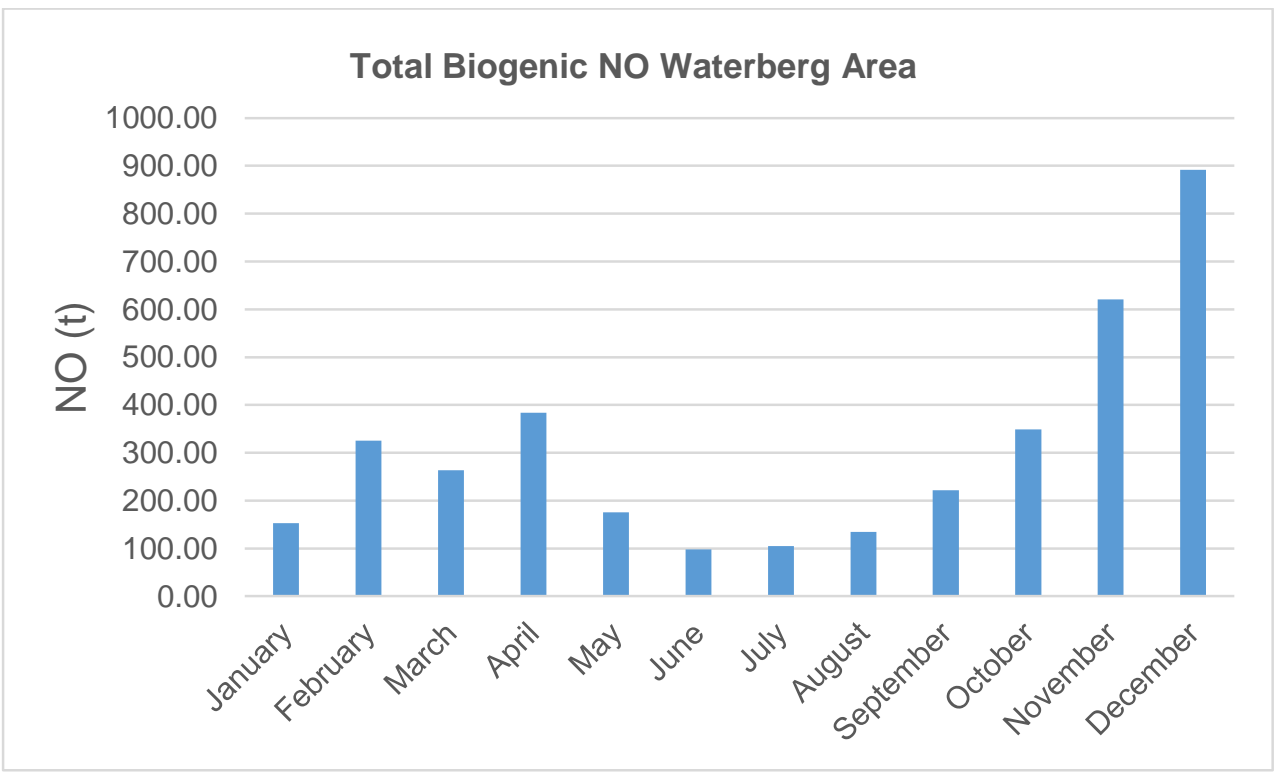


Fig 13: Predicted total annual nitrogen deposition $\left(\mathrm{kg} \mathrm{ha}^{-1} \mathrm{yr}^{-1}\right)$, below average rainfall year 2003 


\section{CONCLUSIONS}

A comprehensive model simulating biogenic soil NOx emission was built using work previously done by Yienger and Levy (1995) for both the Highveld and Waterberg priority areas located within South Africa. This was done in conjunction with existing sulfur and nitrogen dispersion models constructed in CALPUFF to build toward more complete emission inventories for those regions as well as understanding the effect the added biogenic $\mathrm{NO}$ x will have on $\mathrm{N}$ deposition within those areas.

In the case for the Highveld biogenic $\mathrm{NO}_{x}$ emitted made up $3.96 \%, 4.14 \%$ and $3.34 \%$ of total released $\mathrm{NO}_{x}$ for the three modelling period of 2001, 2003 and 2010 respectively. This is significantly more than is released by household fuel burning, small industrial sources and biomass burning.

Biogenic emissions for the Waterberg area were only $2.3 \%$ of total NOx emissions. But because biogenic emissions were so low compared to NOx emission from both the power stations, it was decided not to run a dispersion model as the effect on nitrogen dispersion and deposition will be minimal.

For the Highveld area though dry $\mathrm{N}$ deposition rates were the most affected by biogenic NOx emissions, with higher deposition rates predicted at all receptor locations. The highest NOx emissions were predicted during spring and autumn months. Dry nitrogen deposition rates have been affected the most. Biogenic NOx added between $1.69-6.19$ $\%$. Wet deposition rates were affected very little $(0.13 \%$ to $0.75 \%)$, while total nitrogen deposition rates ranged from $0.32 \%$ to $1.77 \%$.

Although biogenic NO is predicted to contribute up to $30 \%$ of the total NO concentration over certain Highveld areas, the overall contribution to $\mathrm{N}$ species deposition is less than $2 \%$ of which the majority is contributed by the dry deposition mechanism.

Recommendations for further study: 
- Fertilizer used in crops could have a significant effect biogenic on $\mathrm{NO} x$ and $\mathrm{NH}_{4}{ }^{+}$ volatilization. Land use should therefore be more accurately mapped to distinguish more clearly between agricultural fields, grasslands and savanna biomes.

- Fertilizer loads (timing and amount of fertilizer added by farmers) should be considered. Large areas of the Highveld are covered with crops. This would affect biogenic NOx emissions for the area.

- Accurate biogenic NO flux rates should be determined specifically for the grasslands on the South African Highveld, which would result in a more accurate model. 


\section{Acknowledgements}

Considerable assistance was rendered by the staff of Airshed Planning Professionals (Pty) Ltd with aspects of CALPUFF modelling. Ms Rochelle Bornman produced the map. 


\section{REFERENCES}

Bird, T.L. (2011). Some impacts of sulfur and nitrogen deposition on the soils and surface waters of the Highveld grasslands, South Africa. PhD thesis, Faculty of Science, University of the Witwatersrand,

Bluff, E., Turner, C.R., \& de Beer, G.H. (1991). Rain Chemistry 1985-1990. Eskom Report TRR/S91/016.

Davidson, E.A., \& Kingerlee, W. (1997). A global inventory of nitric oxide emissions from soils. Nutrient Cycling Agroecosystems, 48, 37-50, 1997.

Feig, G.T. (2009). Soil Biogenic Emissions of Nitric Oxide from Arid and Semi-Arid Ecosystems. PhD thesis, Johannes Gutenberg University, Mainz.

Feig, G.T., Mamtimin, B., \& Meixner, F.X. (2008). Soil Biogenic emissions of nitric oxide from a semi-arid savanna in South Africa. Biogeosciences, 5, 1723-1738.

Galy-Lacaux, C., Al Ourabi, H., Galloway, J., Lacaux, J.P., Mphepya, J., Pienaar, K., Pont, V., Sigha, L., \& Yoboué, V. (2003). Dry and wet atmospheric nitrogen deposition in Africa. IGACtivities Newsletter of the International Global Atmospheric Chemistry Project, DEBITS Special Issue $n^{\circ 2} 27,2003$.

Held, G., \& Mphepya, J.N. (2000). Wet and dry deposition in South Africa. Proceedings at XI Congresso Brasiliero de Meteorologia (CD), pp. 2824-2833, SBMET, Rio de Janeiro, 2000.

Hutchinson, L. (2012). An initial investigation into key soil processes and associated influences on $N$ and $S$ cycles of a grassland site near a coal-fired power station, Mpumalanga, South Africa. MSc dissertation, University of the Witwatersrand, Johannesburg.

Josipovic, M., Annegarn, HJ., Kneen, M.A., Pienaar, J.J., \& Piketh, S.J. (2011). Atmospheric dry and wet deposition of sulphur and nitrogen species and assessment of critical loads of acidic deposition exceedance in South Africa. S Afr J Sci. 2011; 107(3/4), DOI: 10.4102/ sajs.v107i3/4.478 
Liebenberg-Enslin, H., von Reiche, V., \& Petzer, G. (2010). Waterberg Coal-fired Power Stations EIA and EMP: Air Quality Study, Project done on behalf of Aurecon (Pty) Ltd. Report No. APP/09/AUR-01 October 2010.

Lowman, G.R.P. (2003). Deposition of Nitrogen to Grasslands Versus Forested Areas in the Vicinity of Sabie, Mpumalanga, South Africa. MSc Thesis, Johannesburg: University of the Witwatersrand School of Animal, Plant and Environmental Sciences.

Merrill, M.D., and Tewalt, S.J. (2008) GIS representation of coal-bearing areas in Africa. U.S. Geological Survey Open-File Report 2008-1258.

https://pubs.usgs.gov/of/2008/1258/. Accessed 5 July 2017.

Mphepya, J.N., \& Held, G. (1999). Deposition studies in 1999. Eskom Report, RES/RE/00/10399.

Musina, L., Rutherford, M C., and Powrie, L W. (2009) The Vegetation Map of South Africa, Lesotho and Swaziland. Version 2009. South African National Biodiversity Institute . http://bgis.sanbi.org/SpatialDataset/Detail/331. Accessed 5 July 2017.

Pretorius, I. (2015) Impacts and control of coal-fired power station emissions in South Africa. PhD Thesis, Potchefstroom, North West University, Department of Geography and Environmental Management.

Scholes, M.C., Martin, R., Scholes, R.J., Parsons, D., \& Winstead, E. (1997). NO and $\mathrm{N}_{2} \mathrm{O}$ emissions from savanna soils following the first simulated rains of the season. Nutrient Cycling in Agroecosystems, 48, 115-122.

Scholes, R.J., \& Scholes, M.C. (1998) Natural and human related sources of ozoneforming trace gases in southern Africa. South African Journal of Science, 93, 1-4.

Scorgie, Y., Marjanovic, P., Blight, J., \& Burger, L.W. (2002). Impact of atmospheric deposition due to Eskom Power Stations on Grootdraai Dam water quality. Eskom Report, RES/RR/01/15655, January 2002.

Scorgie, Y., \& Kornelius, G. (2009). Investigation into the effects of atmospheric pollutants on the soil-water-ecosystem continuum, Phase 0 - Concept design, Atmospheric workLiterature review and modelling of acid deposition over the Highveld. Project completed 
by Airshed Planning Professionals Pty Ltd on behalf of Eskom Holdings Ltd, Report No. APP/08/ESKOM-01 Rev 0, May 2009.

Williams, E.J., Guenther, A., \& Fehsenfeld, F.C. (1992). An inventory of nitric oxide emissions from soils in the United States. Journal of Geophysical Research -

Atmospheres, 97, 7511-7519.

Yienger, J.J., \& Levy, H. II (1995). Empirical model of global soil-biogenic NOx emissions. Journal of Geophysical Research - Atmospheres, 100, 11447-11464.

Zunckel, M. (1999). Dry deposition of sulphur over eastern South Africa. Atmospheric Environment, 33, 3515-3529. 